Prepared in cooperation with the U.S. Army Corps of Engineers

\title{
Temporal and Spatial Monitoring of Cyanobacterial Blooms at Willow Creek Reservoir, North-Central Oregon
}

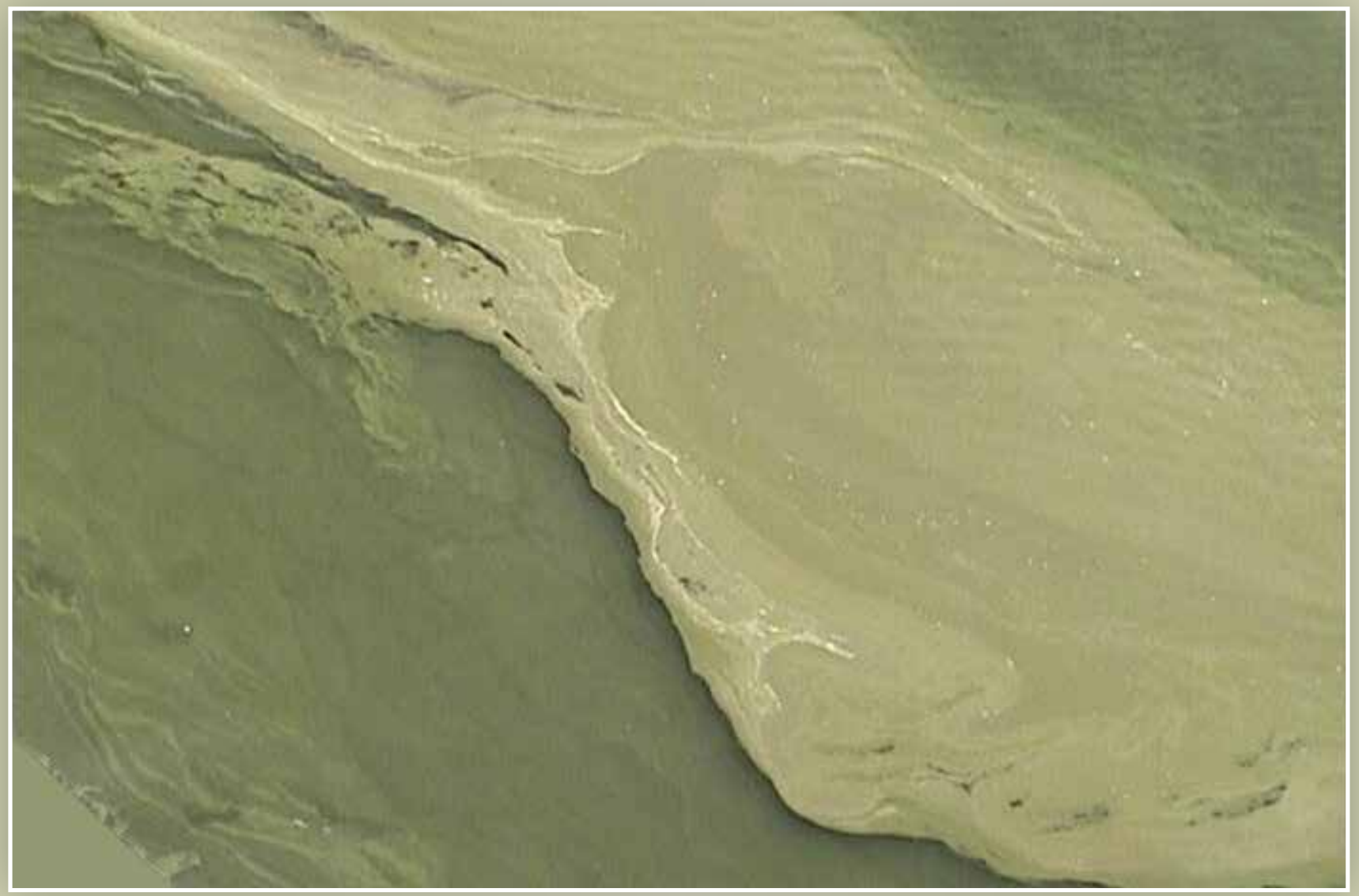

Scientific Investigations Report 2018-5083 
Cover: An algal surface accumulation occurring in the northwestern corner of Willow Creek Reservoir, north-central, Oregon, September 23, 2015, at 1009 PDT. Photograph by U.S. Geological Survey. 


\section{Temporal and Spatial Monitoring of Cyanobacterial Blooms at Willow Creek Reservoir, North-Central Oregon}

By Cassandra D. Smith

Prepared in cooperation with the U.S. Army Corps of Engineers

Scientific Investigations Report 2018-5083 


\section{U.S. Department of the Interior \\ RYAN K. ZINKE, Secretary}

\section{U.S. Geological Survey James F. Reilly II, Director}

\section{U.S. Geological Survey, Reston, Virginia: 2018}

For more information on the USGS - the Federal source for science about the Earth, its natural and living resources, natural hazards, and the environment-visit https://www.usgs.gov/ or call 1-888-ASK-USGS.

For an overview of USGS information products, including maps, imagery, and publications, visit https:/store.usgs.gov.

Any use of trade, firm, or product names is for descriptive purposes only and does not imply endorsement by the U.S. Government.

Although this information product, for the most part, is in the public domain, it also may contain copyrighted materials as noted in the text. Permission to reproduce copyrighted items must be secured from the copyright owner.

Suggested citation:

Smith, C.D., 2018, Temporal and spatial monitoring of cyanobacterial blooms at Willow Creek Reservoir, north-central Oregon: U.S. Geological Survey Scientific Investigations Report 2018-5083, 26 p., https://doi.org/10.3133/sir20185083.

SSN 2328-0328 (online) 


\section{Contents}

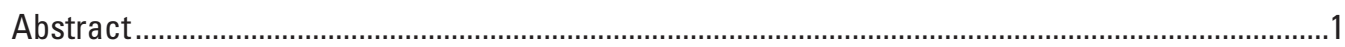

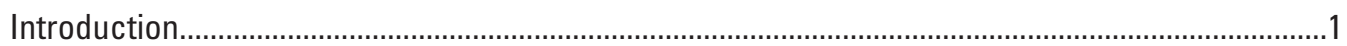

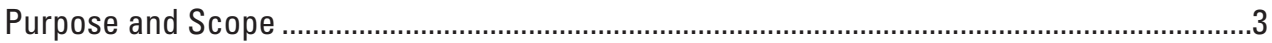

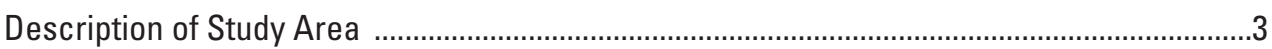

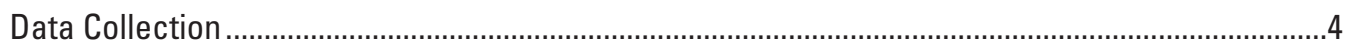

Northwestern Corner Continuous Water-Quality Monitoring ....................................................

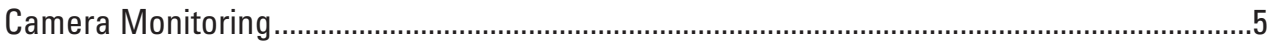

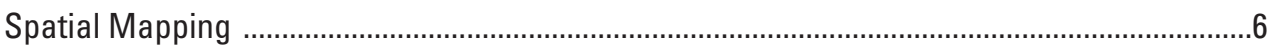

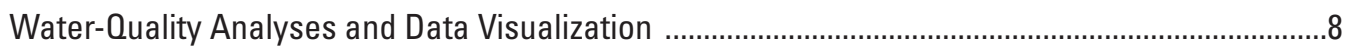

Northwestern Corner Continuous Water-Quality Monitoring Results .........................................8

Camera Monitoring Results .................................................................................................12

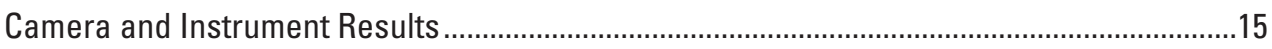

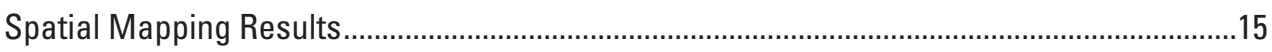

Temporal and Spatial Monitoring of Cyanobacterial Blooms.........................................................19

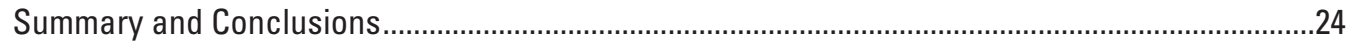

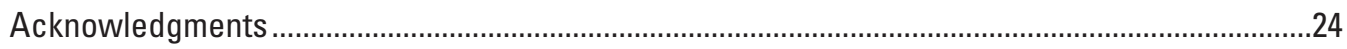

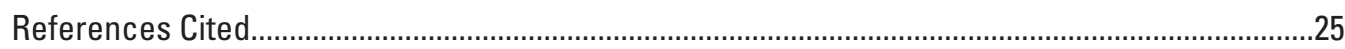

\section{Figures}

1. Map showing Willow Creek Reservoir near the town of Heppner, Oregon .......................4

2. Aerial image showing locations of a surveillance camera and the five camera image positions at Willow Creek Reservoir, north-central Oregon....................................6

3. Aerial image of surface transects for mapping water quality in Willow Creek Reservoir, north-central Oregon .....................................................................................

4. Graph showing hourly $\mathrm{pH}$ and dissolved oxygen percent saturation data during May-September 2015 at the fixed location in the northwestern corner of Willow Creek Reservoir, north-central Oregon

5. Graph showing hourly total chlorophyll and turbidity data during May-September 2015 at the fixed location in the northwestern corner of Willow Creek Reservoir, north-central Oregon .

6. Graph showing median, 10th-90th percentiles, and the 25th-75th percentiles for blue-green algae phycocyanin data collected during May-September 2015 at the fixed location in the northwestern corner of Willow Creek Reservoir, north-central Oregon ...

7. Two images of a cyanobacterial bloom in Willow Creek Reservoir taken 15 minutes apart from the same position on May 21, 2015

8. Images taken by the Axis 214 camera in the northwestern corner of Willow Creek Reservoir, north-central Oregon, showing four types of image quality...

9. Images taken by the Axis 214 camera in the northwestern corner of Willow Creek Reservoir, north-central Oregon, showing functionality of website.. 


\section{Figures-Continued}

10. Graph showing comparison of the total chlorophyll data from the continuous water-quality instrument and the camera images

11. A colorized map representing relative total chlorophyll concentrations throughout the reservoir at 1.5 feet deep on September 16, 2016, from 1150 and 1400 PDT

12. A colorized map representing water temperature throughout the reservoir at 1.5 feet deep on September 16, 2016, from 1150 to 1400 PDT.

13. A colorized map representing relative blue-green algae phycocyanin concentrations throughout the reservoir at 1.5 feet deep on September 16, 2016, from 1150 and 1400 PDT

14. An algal surface accumulation occurring in the northwestern corner of Willow Creek Reservoir, north-central, Oregon, November 7, 2016, at 1223 PST

15. An algal bloom occurring along the dam face in Willow Creek Reservoir, north-central Oregon, September 26, 2016, at 1150 PDT.

16. An algal surface accumulation occurring in the northwestern corner of Willow Creek Reservoir, north-central Oregon, September 28, 2016, at 1048 PDT .

17. A boat paddles through an algal bloom occurring in the northwestern corner of Willow Creek Reservoir, north-central Oregon, October 10, 2016, at 1109 PDT.

\section{Tables}

1. Descriptions of type of equipment, type of data collected, and dates of data collection during 2015 and 2016 field seasons at Willow Creek Reservoir, north-central Oregon

2. Comparison of the YSI EXO2 multi-parameter water-quality readings measured at the same location in Willow Creek Reservoir, north-central Oregon, June 9, 2015 


\section{Conversion Factors}

U.S. customary units to International System of Units

\begin{tabular}{lcl}
\hline \multicolumn{1}{c}{ Multiply } & By & \multicolumn{1}{c}{ To obtain } \\
\hline inch (in.) & Length & \\
inch (in.) & 2.54 & centimeter $(\mathrm{cm})$ \\
foot (ft) & 25.4 & millimeter $(\mathrm{mm})$ \\
mile (mi) & 0.3048 & meter (m) \\
\hline & 1.609 & kilometer $(\mathrm{km})$ \\
\hline acre & Area & \\
acre & 4,047 & square meter $\left(\mathrm{m}^{2}\right)$ \\
acre & 0.4047 & hectare $($ ha) \\
acre & 0.4047 & square hectometer $\left(\mathrm{hm}^{2}\right)$ \\
\hline & 0.004047 & square kilometer $\left(\mathrm{km}^{2}\right)$ \\
\hline acre-foot (acre-ft) & Volume & \\
acre-foot (acre-ft) & 1,233 & cubic meter $\left(\mathrm{m}^{3}\right)$ \\
& 0.001233 & cubic hectometer $\left(\mathrm{hm}^{3}\right)$ \\
\hline mile per hour (mi/h) & Speed & \\
\hline
\end{tabular}

Temperature in degrees Celsius $\left({ }^{\circ} \mathrm{C}\right)$ may be converted to degrees Fahrenheit $\left({ }^{\circ} \mathrm{F}\right)$ as follows:

$$
{ }^{\circ} \mathrm{F}=\left(1.8 \times{ }^{\circ} \mathrm{C}\right)+32 .
$$

\section{Datum}

Horizontal coordinate information is referenced to the North American Datum of 1983 (NAD 83).

\section{Supplemental Information}

Specific conductance is given in microsiemens per centimeter at 25 degrees Celsius $\left(\mu \mathrm{S} / \mathrm{cm}\right.$ at $\left.25^{\circ} \mathrm{C}\right)$.

Concentrations of chemical constituents in water are given in either milligrams per liter (mg/L) or micrograms per liter ( $\mu \mathrm{g} / \mathrm{L})$. 



\title{
Temporal and Spatial Monitoring of Cyanobacterial Blooms at Willow Creek Reservoir, North-Central Oregon
}

\author{
By Cassandra D. Smith
}

\begin{abstract}
The U.S. Geological Survey (USGS) and U.S. Army Corps of Engineers (USACE) investigated the spatial and temporal dynamics of cyanobacterial (blue-green algal) blooms in Willow Creek Reservoir in north-central Oregon in 2015-16. A combination of cameras and water-quality monitoring equipment was used to assess the frequency and duration of blooms and their effects on water quality. A surveillance camera captured color images every 15 minutes during daylight hours of the northwestern corner of Willow Creek Reservoir, where surface blooms tend to accumulate due to the prevailing summer winds. In 2015, a water-quality instrument was deployed in the northwestern corner of the reservoir to continuously measure water temperature, $\mathrm{pH}$, dissolved oxygen, specific conductance, turbidity, total chlorophyll, and the blue-green algae pigment phycocyanin. In 2016, a water-quality instrument was used to collect measurements along transects throughout the reservoir to create spatial maps of water quality. The spatially integrated mapping process was repeated on three different days under varying algal conditions. Also in 2016, a telemetry connection was established allowing resource managers to view the reservoir images in near-real time.

Results from 2015 indicate that surface accumulations of cyanobacteria can form and dissipate within minutes in the reservoir, and that blooms can cause substantial changes to water quality. A persistent cyanobacterial bloom in August and September 2015 resulted in $\mathrm{pH}$ values of 9.5 standard units, 220 percent oxygen saturation, and pronounced increases in turbidity and total chlorophyll. The stationary water-quality instrument collected data during periods with and without blooms, increasing our understanding of the effects of
\end{abstract}

blooms on water quality and revealing potential restoration benchmarks for the freshwater reservoir. The spatially integrated mapping data showed the variation in water quality across the reservoir that occurs during blooms and baseline conditions and indicated regions of the reservoir to focus restoration efforts. Additional spatial data collection can be timed to collect daily extremes.

The camera deployment in 2016 demonstrated that telemetering images from remote sites is possible and provides valuable and timely information. Monitoring with a surveillance camera is inexpensive and supplies data regarding surface-bloom presence or absence. The use of a camera can help target site visits to periods when blooms are observed, which may increase the accuracy of beginning and ending dates for water body closures.

Monitoring cyanobacterial blooms in Willow Creek Reservoir with multiple devices provided a more comprehensive dataset than any one monitoring method. The camera images showed when a surface bloom initiated and dissipated while the water-quality instrument revealed the magnitude, or potential severity, of the effects on water quality.

\section{Introduction}

Cyanobacteria, also known as blue-green algae, are photosynthetic bacteria that are ubiquitous in aquatic ecosystems around the world (Falconer and Humpage, 2005). When exposed to ideal conditions, cyanobacteria can proliferate and form blooms, which can be defined by high cell densities, visible surface accumulations (appearing as green scum), or by the dominance of a single or few species. In this 
report, the term "bloom" is used to refer to high algal biomass or the resulting surface scums or accumulations. Blooms affect ecosystem health by altering food webs and causing hypoxia (Paerl and others, 2011). Some genera of cyanobacteria have the capacity to produce toxins that can cause animal deaths and acute and chronic human health issues (Falconer, 1991; Carmichael and others, 2001; Chen and others, 2009). Cyanobacterial blooms are not always toxin-producing (Vézie and others, 1998), but blooms indicate the potential for an abundance of organisms with the ability to produce cyanotoxins (Graham and others, 2009). Cyanobacterial harmful algal blooms, commonly referred to as CyanoHABs, negatively impact the economy by increasing water treatment costs at drinking water intakes and through the loss of recreational revenue due to water body closures and aesthetics (U.S. Environmental Protection Agency, 2015).

Factors that influence cyanobacterial blooms include temperature, nutrient availability, wind/mixing, water chemistry, and site-specific traits (Chorus and Bartram, 1999; Briand and others, 2003; Anderson and others, 2012; Van der Merwe and Price, 2015). The combination of those factors will affect the temporal and spatial characteristics of the bloom (Anderson and others, 2012). Water bodies with warm, eutrophic water experiencing calm weather may have intense or prolonged blooms (Kanoshina and others, 2003), especially if cyanobacterial blooms have occurred in that water body in the past. Specific cyanobacterial cells (known as akinetes) can persist from year to year, making it difficult to break the seasonal bloom trend (Falconer and Humpage, 2005). Population growth and increased nutrient runoff, coupled with warmer temperatures, may cause an increase in the frequency and duration of cyanobacterial blooms in the future.

The U.S. Environmental Protection Agency (EPA) established recreational guidelines for cyanotoxins, which recommend that swimming advisories be posted if microcystin and cylindrospermopsin concentrations exceed 4 and $8 \mu \mathrm{g} / \mathrm{L}$, respectively (U.S. Environmental Protection Agency, 2017). Technology is rapidly evolving in this field, but at the present time, inexpensive and reliable sensors that can be deployed to detect cyanotoxins are not available. Collecting discrete samples for toxins, cell count, and taxonomic identification is currently the most common way to identify a HAB and to issue an advisory or water body closure (Graham and others, 2009). The Oregon Health Authority (2016) recommends that samples are collected when temperatures are warm and from locations where humans and animals would likely contact the water. In States that do not receive Federal funding for toxin sampling, the ability to sample the impaired water body and to post closures depends on management decisions in allocation of State resources. Toxin sampling can be costly and time-intensive, as many water bodies used for recreation are in remote areas. Therefore, discrete toxin sampling is often infrequent (for example, biweekly) or does not occur.

Recent monitoring techniques have utilized satellite imagery to detect algal biomass occurrence, spatial extent, and trends (Stumpf, 2001; Urquhart and others, 2017). Satellite sensors that distinguish cyanobacterial wavelengths and are available to the public (such as the European Space Agency's MERIS) can be valuable tools. However, satellite monitoring can be inconclusive or problematic due to satellite flyover intervals, cloud cover, or imagery resolution. Remote sensing using a coarse resolution (ex: Landsat 8 with 30 -m pixels) can obscure finer scale spatial trends in bloom occurrence, and this problem is compounded with smaller water bodies. There is a need to develop a monitoring approach that is inexpensive, high frequency (to characterize algal biomass dynamics), and can be implemented in remote water bodies of all sizes.

Deploying a color surveillance camera is one monitoring method that can address the problems of infrequent site visits and the resolution and periodicity of remote imagery flyovers. Programmable color surveillance cameras with appropriate lenses and pan/tilt/zoom capabilities take pictures at multiple angles and can save them locally, as well as transmit them via cellular connection. These images could indicate the presence of a surface bloom, and short image intervals would show the onset, duration, and dissipation. Continuously monitoring water chemistry could also provide timely indications that a bloom is occurring. A continuous water-quality instrument can measure temperature, $\mathrm{pH}$, dissolved oxygen, specific conductance, turbidity, total chlorophyll, and blue-green algae - phycocyanin (BGA-PC; a pigment specific to cyanobacteria) parameters to both confirm the imagery and provide the physicochemical context for the occurrence of the blooms.

Some water-quality parameters can influence cyanobacterial blooms, and multiple parameters are affected by blooms. Growth rates of cyanobacteria increase in warm water temperatures (Johnk and others, 2008), and monitoring water temperature data may indicate when high algal biomass is likely to occur. Cyanobacteria photosynthesize and respire in the presence of light but only respire in the absence of sunlight. Photosynthesis and respiration rates result in daily cycles in dissolved oxygen concentrations and $\mathrm{pH}$, and the presence of a bloom often increases the magnitude and the variation of the daily data (Maberly, 1996; Staehr and others, 2010). Biological activity including photosynthesis and respiration can affect the percent oxygen saturation, and high algal biomass can result in readings greater than 100 percent while algal die-offs may result in hypoxic and anoxic conditions. 
Discharge and runoff events transport suspended sediment and nutrients (nitrogen and phosphorus) that can promote bloom occurrence. Turbidity is an optical property of water that is influenced by suspended particles and dissolved compounds (Wagner and others, 2006). While turbidity sensors effectively measure the light-scattering effects of fine, reflective particles in the water column, algal filaments and colonies also may be detected (Sadar, 1998). Algal and cyanobacterial blooms with high cell densities can increase turbidity in a water body (Paerl and Huisman, 2008), and water-quality data can reflect a positive correlation with turbidity and cyanobacteria abundance. Chlorophyll concentrations increase as photosynthetic biomass (green algae and blue-green algae) increases, and BGA-PC increases as cyanobacteria abundance increases. Monitoring chlorophyll and BGA-PC fluorescence shows relative patterns when cyanobacteria are proliferating and decreasing.

Willow Creek Reservoir is a recreational destination in Oregon that is affected by frequent CyanoHABs during the summer (Harris and others, 2014). Due to the remote location of the reservoir, a monitoring technique that minimizes site visits and provides near-real time information would assist in decision-making about water body safety and closures. This report describes a proof-of-concept monitoring study conducted at Willow Creek Reservoir that used existing camera technology and water-quality instrumentation and tested the utility of information provided to the resource managers.

\section{Purpose and Scope}

This research was conducted to (1) evaluate multiple monitoring devices and data collection methodology, (2) establish an early warning system of cyanobacterial blooms, and (3) to increase our understanding of cyanobacterial blooms in Willow Creek Reservoir by monitoring the effects of cyanobacterial blooms on the reservoir's water quality. This report documents the data collected by USGS from Willow Creek Reservoir in 2015 and 2016 and draws conclusions regarding the utility of the various monitoring devices, including the circumstances under which they may be most applicable to other water bodies that tend to produce cyanobacterial blooms.

\section{Description of Study Area}

Willow Creek Reservoir is in north-central Oregon within Morrow County and near the town of Heppner (fig. 1). Heppner, Oregon, is in the U.S. EPA-designated Columbia Plateau ecoregion, and specifically in the Umatilla
Plateau ecoregion. This region is characterized by a plateau of Columbia River Basalt, few trees, and loess deposits of varying thickness that are farmed. The area surrounding the reservoir includes numerous farms that primarily cultivate wheat.

Willow Creek Dam was built in 1983 by the USACE for flood risk reduction, and the dam impounds Willow Creek and Balm Fork Creek to create Willow Creek Reservoir. The 125-acre reservoir can hold a maximum of 13,250 acre-ft of water, and USGS operates streamgages (U.S. Geological Survey, 2018a) on an incoming tributary (streamgage No. 14034470), the outflow from the dam (streamgage No. 14034500), and historically operated a stream gage on the other incoming tributary (streamgage No. 14034480).

Willow Creek Reservoir contains high total phosphorus concentrations, potentially due to high phosphorus concentrations in the basalt parent material (Abrams and Jarrell, 1995; Porder and Ramachandran, 2012), and has been studied and managed for its frequent cyanobacterial blooms. Water samples collected from 1984 to 1996 were examined by Aquatic Analysts, Incorporated (Larson, 1997). Six genera of cyanobacteria were identified including Dolichospermum sp. (formerly Anabaena), Aphanizomenon sp., Chroococcus sp., Gloeotrichia sp., Microcystis sp., and Oscillatoria sp. (Larson, 1997). The cyanobacterial blooms are a concern to resource managers and toxin sampling began in the reservoir in 2006 (Harris and others, 2014). The dominant genus of cyanobacteria during the 2015 and 2016 bloom seasons was Dolichospermum (formerly Anabaena) or Aphanizomenon, and Green Water Laboratories (Palatka, Florida) documented a shift in the planktonic community from dominance of Dolichospermum in May 2015 to dominance of Aphanizomenon in October 2015 (Green Water Laboratories, unpub. data). Due to the prevailing winds at Willow Creek Reservoir, any cyanobacterial surface scums tend to accumulate in the northwestern corner of the reservoir against the dam.

In addition to the routine toxin sampling, multiple studies have been conducted in the reservoir to increase understanding of the system and to experiment with mitigation techniques. Researchers constructed large mesocosms in the reservoir and manipulated the total nitrogen to total phosphorus (TN:TP) ratio. Results indicated that adding ammonium nitrate (to increase the TN:TP) decreased cyanobacteria abundance and toxin concentration while increasing water clarity (Harris and others, 2014). One study experimented with nutrient removal by deploying solar-powered water-circulating devices in Willow Creek Reservoir, and current research involves quantifying the phosphorus flux into the reservoir through sediments (Frank Wilhelm and Sarah Burnet, University of Idaho, unpub. data). 


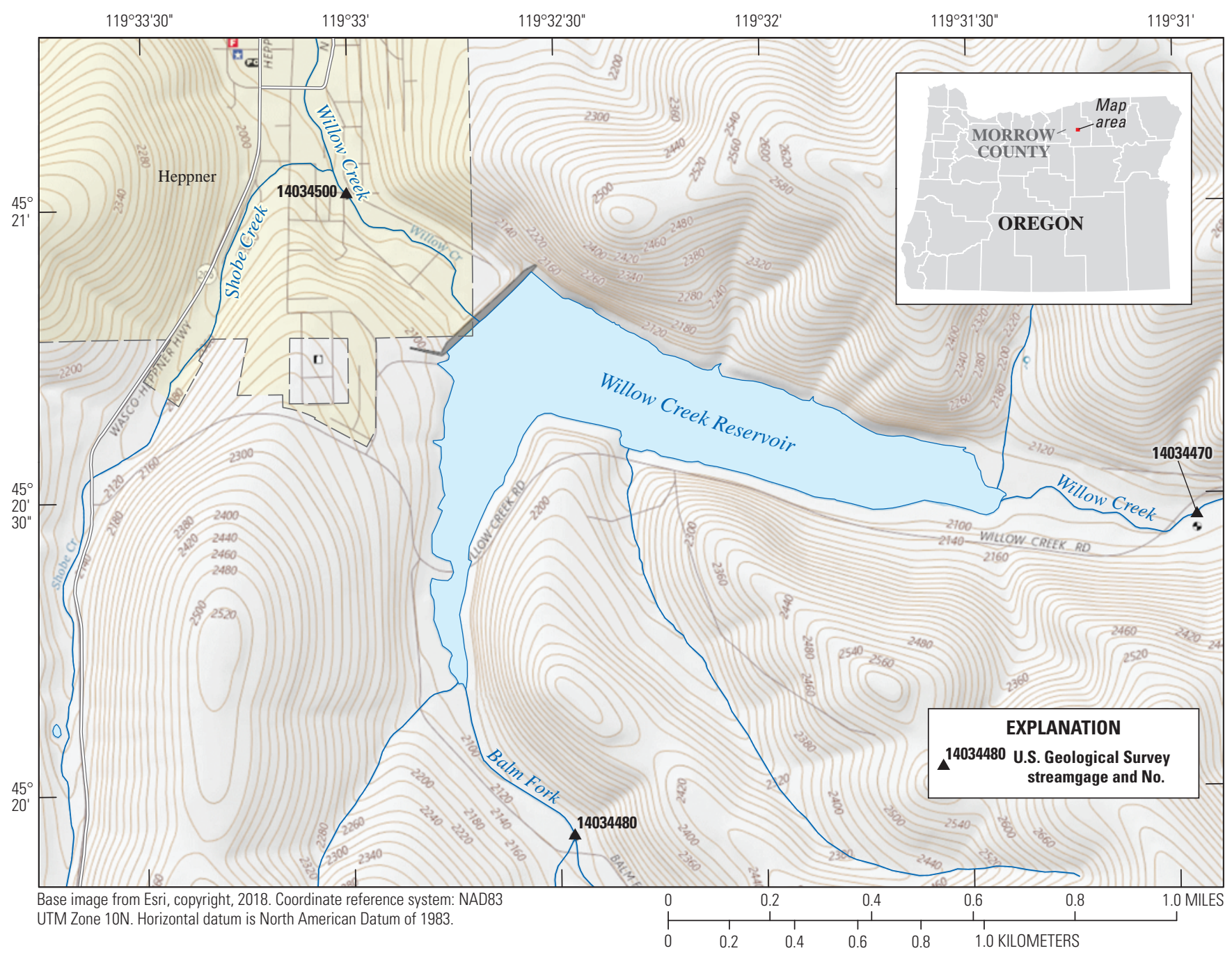

Figure 1. Willow Creek Reservoir near the town of Heppner, Oregon.

\section{Data Collection}

Multi-parameter water-quality instruments and a color surveillance camera were used to collect data regarding algal conditions (table 1).

\section{Northwestern Corner Continuous Water-Quality Monitoring}

A Yellow Springs Instrument (YSI) EXO2 waterquality instrument with probes for seven parameters (water temperature, specific conductance, $\mathrm{pH}$, dissolved oxygen, turbidity, total chlorophyll, and blue-green algaephycocyanin) was programmed to log internally and hourly.
The water-quality instrument was housed in a 3-ft segment of PVC pipe, and 1-inch holes were liberally drilled throughout the pipe to allow free-flowing water to the probes. The PVC housing was attached to buoys and was positioned to remain horizontal with the probes $1.5 \mathrm{ft}(0.5 \mathrm{~m})$ below the surface of the water. Chain and concrete anchors were used to keep the instrument in place; the instrument continued to measure water generally in the same location as the water level declined throughout the summer season and the extra slack in the chain allowed the instrument to slightly migrate from the original location. The instrument was deployed in the northwestern corner of the reservoir where surface blooms accumulate, approximately $75 \mathrm{ft}$ from the dam, and directly across from the camera on the dam. 
Table 1. Descriptions of type of equipment, type of data collected, and dates of data collection during 2015 and 2016 field seasons at Willow Creek Reservoir, north-central Oregon.

[YSI, Yellow Springs Instrument]

\begin{tabular}{l|l|l}
\hline \multicolumn{1}{c|}{ Type of equipment } & \multicolumn{1}{c}{ Type of data collected } & \multicolumn{1}{c}{ Dates of data collection } \\
\hline $\begin{array}{l}\text { YSI EXO2 multi-parameter water- } \\
\text { quality instrument }\end{array}$ & $\begin{array}{l}\text { Continuous (hourly) water-quality data from one } \\
\text { location in the northwestern corner of the reservoir. }\end{array}$ & May 13 to Sept. 21, 2015 \\
\hline Axis 214 color surveillance camera & $\begin{array}{l}\text { Five images of the northwestern corner of the reservoir } \\
\text { every 15 minutes during daylight hours. }\end{array}$ & $\begin{array}{l}\text { May 14 to Nov. 9, 2015 (not telemetered) } \\
\text { July 20 to Nov. 22, 2016 (telemetered) }\end{array}$ \\
\hline $\begin{array}{l}\text { YSI EXO2 multi-parameter water- } \\
\text { quality instrument }\end{array}$ & Spatial water-quality data throughout the reservoir. & June 9, 2015; Aug. 17, 2016; Sept. 16, 2016 \\
\hline
\end{tabular}

A clean and calibrated instrument was deployed on May 13, 2015 and monthly site visits were conducted following standard USGS protocols (Wagner and others, 2006). At each site visit, the instrument was cleaned and then swapped with a newly calibrated EXO2. During site visits, a wide-mouth 1-L polypropylene bottle was inverted in the water next to the instrument probes (1.5 ft deep) and filled, taking care to avoid the collection of any surface scum. The sample water was added to an 8-L polyethylene churn sample splitter (Wilde and others, 2004), and this process was repeated until the churn sample splitter contained approximately $6 \mathrm{~L}$ of water. The EXO2 water-quality instrument was positioned in the churn sample splitter, and multiple total chlorophyll readings were logged and averaged. The composite water sample was homogenized using the churn paddle and two 1-L subsamples were dispensed from the spigot. The samples were filtered, frozen, and analyzed at the USGS Oregon Water Science Center using a Trilogy ${ }^{\circledR}$ Laboratory Fluorometer and following EPA Method 445.0 In Vitro Determination of Chlorophyll $a$ (Arar and Collins, 1997).

Following site visits, the internally logged instrument data were downloaded and the appropriate fouling and calibration corrections were applied to the data (Wagner and other, 2006). Calibration corrections to the total chlorophyll record were based on the laboratory readings. All continuous water-quality data are available online in the National Water Information System as site 452053119323001 Willow Creek Reservoir NW Corner, OR (U.S. Geological Survey, 2018a).

\section{Camera Monitoring}

A camera was deployed to observe cyanobacterial surface blooms occurring in Willow Creek Reservoir. An Axis 214 color surveillance camera was chosen for this proofof-concept study because it had the ability to pan, tilt, and zoom, and was programmable. Additionally, the camera could withstand hot temperatures, could be fitted with a polarizing lens to potentially reduce glare, and was able to either store images internally or connect to a wireless network to transmit images.

The camera was positioned above the water and facing downwards to achieve the desired contrast in colors. The camera was attached to a railing of the Willow Creek Dam in the northwestern corner of the reservoir about $70 \mathrm{ft}$ above the surface of the water. The system was powered by a solar panel and large battery, and the camera was programmed to take a series of five pictures every 15 minutes during daylight hours (fig. 2).

During 2015, the camera was installed on May 14 and retrieved on November 9. Site visits occurred at regular intervals and consisted of downloading the stored images and troubleshooting any issues. A polarizing lens specific to the Axis 214 camera was tested from May to July 2015.

The camera was installed at the same location on July 20, 2016, and was retrieved November 22, 2016. Site visits were frequent and multiple modems, antenna, and cellular phone companies were tested to attain consistent telemetry of the images. A script was created that uploaded the telemetered images to a public website in near-real time. 


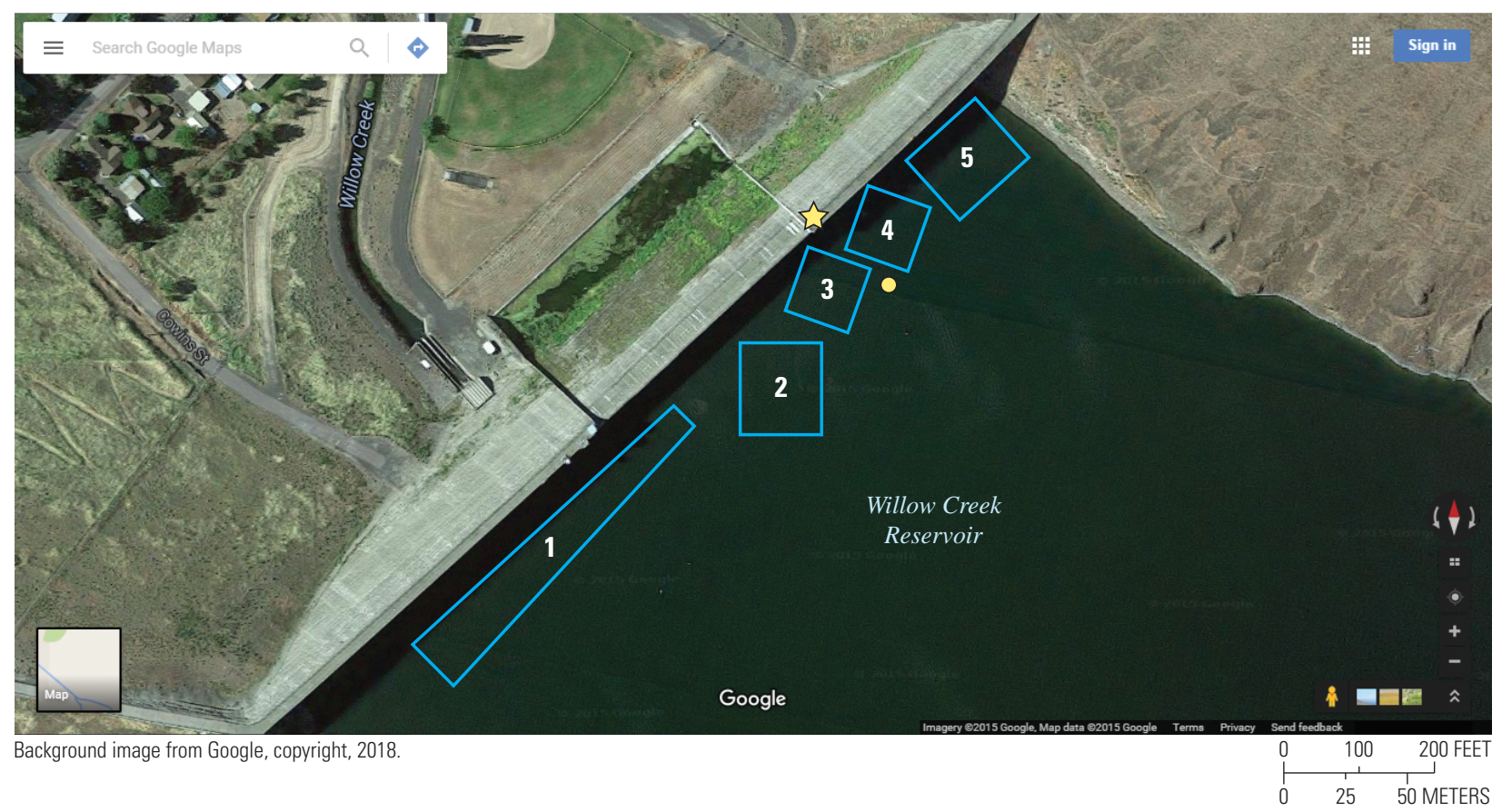

Figure 2. Locations of a surveillance camera and the five camera image positions at Willow Creek Reservoir, north-central Oregon. The location of the camera on the dam is indicated by the five-pointed star, and the numbered rectangles indicate the approximate area captured by each camera image. Position number 1 is photographed first, followed by position number 2, and in order through position number 5. The yellow circle represents the approximate location of the continuous water-quality instrument. Background image is from Google (https://www.google.com/maps/place/Heppner,+0R+97836/@45.3476167,-119.5439632,409m/data=!3m1!1e3!4m5!3m4!1s0x54bcde 9fefa0ff5f:0x8c43eb5baecaeb35!8m2!3d45.3531842!4d-119.5577997, accessed December 21, 2017).

\section{Spatial Mapping}

Surface water in Willow Creek Reservoir was mapped along transects using a water-quality instrument three times in 2015-16. A YSI EXO2 multi-parameter instrument was outfitted to measure seven parameters (water temperature, specific conductance, $\mathrm{pH}$, dissolved oxygen, turbidity, total chlorophyll, and BGA-PC) and programmed to log internally every 10 seconds. The weighted, calibrated YSI EXO2 multiparameter instrument was attached to a boat cleat on the right side at the front of the boat. The boat began data collection at the southern end of the reservoir near location 5 (fig. 3) and progressed about $2.5 \mathrm{mi} / \mathrm{h}$ throughout the reservoir; the speed was chosen to ensure the probes remained submerged $1.5 \mathrm{ft}$ below the surface. A tablet or Trimble GPS unit recorded the GPS track and logged readings every 3 seconds. The boat roughly followed the GPS track (fig. 3) and traversed the reservoir without pausing, ending at the eastern end of the reservoir near location 1 . After the track was completed, discrete chlorophyll- $a$ samples were collected at the accessible locations (1-5); samples were analyzed at the Oregon Water Science Center following the procedures listed above to compare to the instrument measurements. 


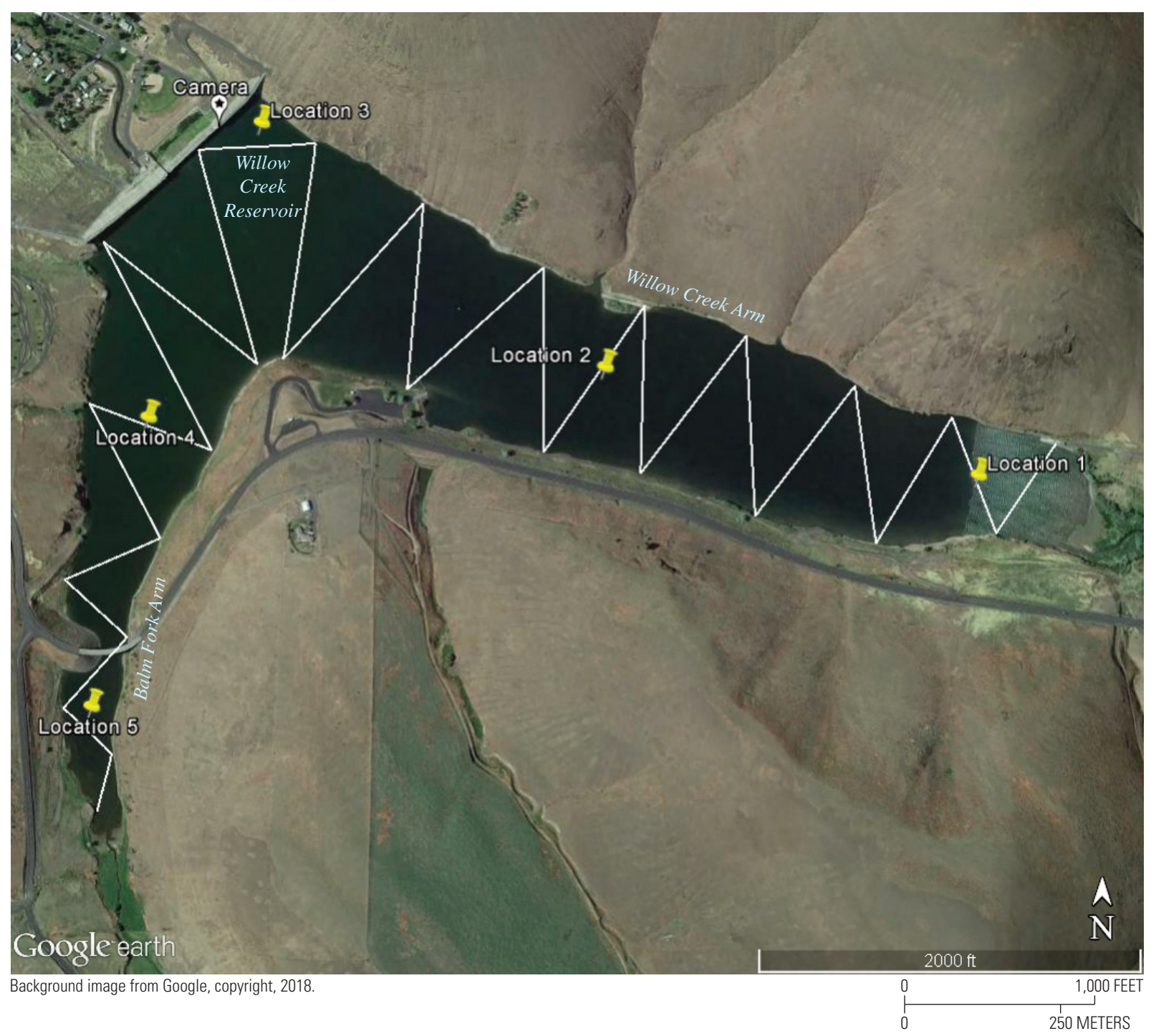

Figure 3. Surface transects for mapping water quality in Willow Creek Reservoir, north-central Oregon. The white line denotes the approximate GPS path the boat followed while logging water-quality parameters with a Yellow Springs Instrument (YSI) EXO2 instrument. The boat returned to locations 1-5 and collected discrete chlorophyll-a water samples. A stationary, continuous instrument was located at location 3 and a surveillance camera location is symbolized by the white marker with a black star. Willow Creek flows into the reservoir from the east and Balm Fork Creek flows into the reservoir from the south. 


\section{Water-Quality Analyses and Data Visualization}

\section{Northwestern Corner Continuous Water-Quality Monitoring Results}

The water-quality instrument measured high frequency data from one location in the reservoir, often where the cyanobacterial surface blooms accumulate. Collecting continuous water-quality data from a bloom-prone location can reveal how the water quality is affected by cyanobacterial blooms. Water temperature ranged from $15.0^{\circ} \mathrm{C}$ on May 14, 2015 to $26.6^{\circ} \mathrm{C}$ on July 2, 2015 and often experienced diel fluctuations of $1{ }^{\circ} \mathrm{C}$ or less. Specific conductance generally increased from May 2015 to early September 2015, with a minimum of $211 \mu \mathrm{S} / \mathrm{cm}$ and a maximum of $252 \mu \mathrm{S} / \mathrm{cm}$. On 59 days during May, August, and September 2015, the pH was greater than or equal to 9.0 standard units and reached a maximum of 9.5 standard units on September 11, 2015 (fig. 4). The percent oxygen saturation at Willow Creek Reservoir was greater than 100 percent for most of the deployment period, and neither anoxic nor hypoxic concentrations were measured at this near-surface location. In September, dissolved oxygen reached 220.5 percent saturation (fig. 4). Turbidity, total chlorophyll, and BGA-PC data have similar trends with pronounced variation and elevated measurements during the May and August/September blooms (fig. 5). Total chlorophyll readings ranged from 0.5 to $115.0 \mu \mathrm{g} / \mathrm{L}$, and based on the total chlorophyll concentrations, the reservoir likely shifted to eutrophic and hypereutrophic states during May and August/September (Carlson and Simpson, 1996). The laboratory-corrected total chlorophyll concentrations may differ from actual values between sample collection dates due to the complexity of phytoplankton communities and the many factors affecting chlorophyll fluorescence. BGA-PC reached a minimum of 0 and maximum of $20.8 \mu \mathrm{g} / \mathrm{L}$ during the deployment (fig. 6); however, the BGA-PC data were not corrected to discrete samples and values are considered relative concentrations.

The instrument data from this study show periods of high algal productivity (characterized by elevated $\mathrm{pH}$ and dissolved oxygen) during May, August, and September 2015. The data show that the percent oxygen saturation at Willow Creek Reservoir was greater than 100 percent saturation throughout most of the study period, which indicates that photosynthesizing organisms in the water column were producing and releasing oxygen. Other optical parameters including the total chlorophyll, turbidity, and BGA-PC also indicated that the water quality was affected in May, August, and September. Specific conductance data decreased for a few days in mid-September, which corresponds to the elevated $\mathrm{pH}$, dissolved oxygen, total chlorophyll, turbidity, and BGA-PC readings. The water was super-saturated with oxygen and it is possible that air bubbles accumulated in the specific conductance probe, decreasing the readings during that time period. 


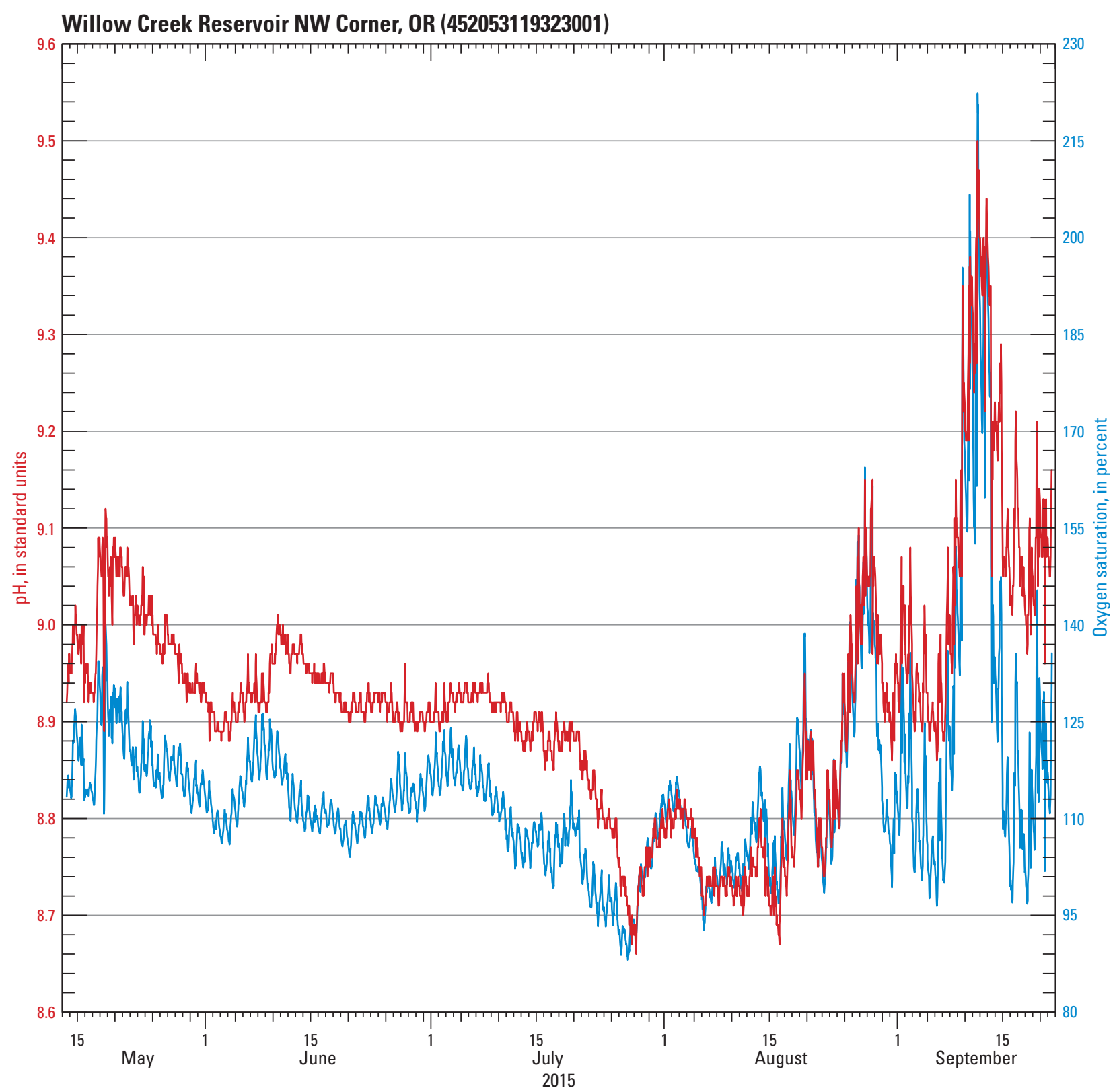

Figure 4. Hourly $\mathrm{pH}$ (standard units) and dissolved oxygen percent saturation data during May-September 2015 at the fixed location in the northwestern corner of Willow Creek Reservoir, north-central Oregon. Oxygen percent saturation values were calculated using algorithms from USGS Data Grapher (U.S. Geological Survey, 2018b). 
Willow Creek Reservoir NW Corner, OR (452053119323001)

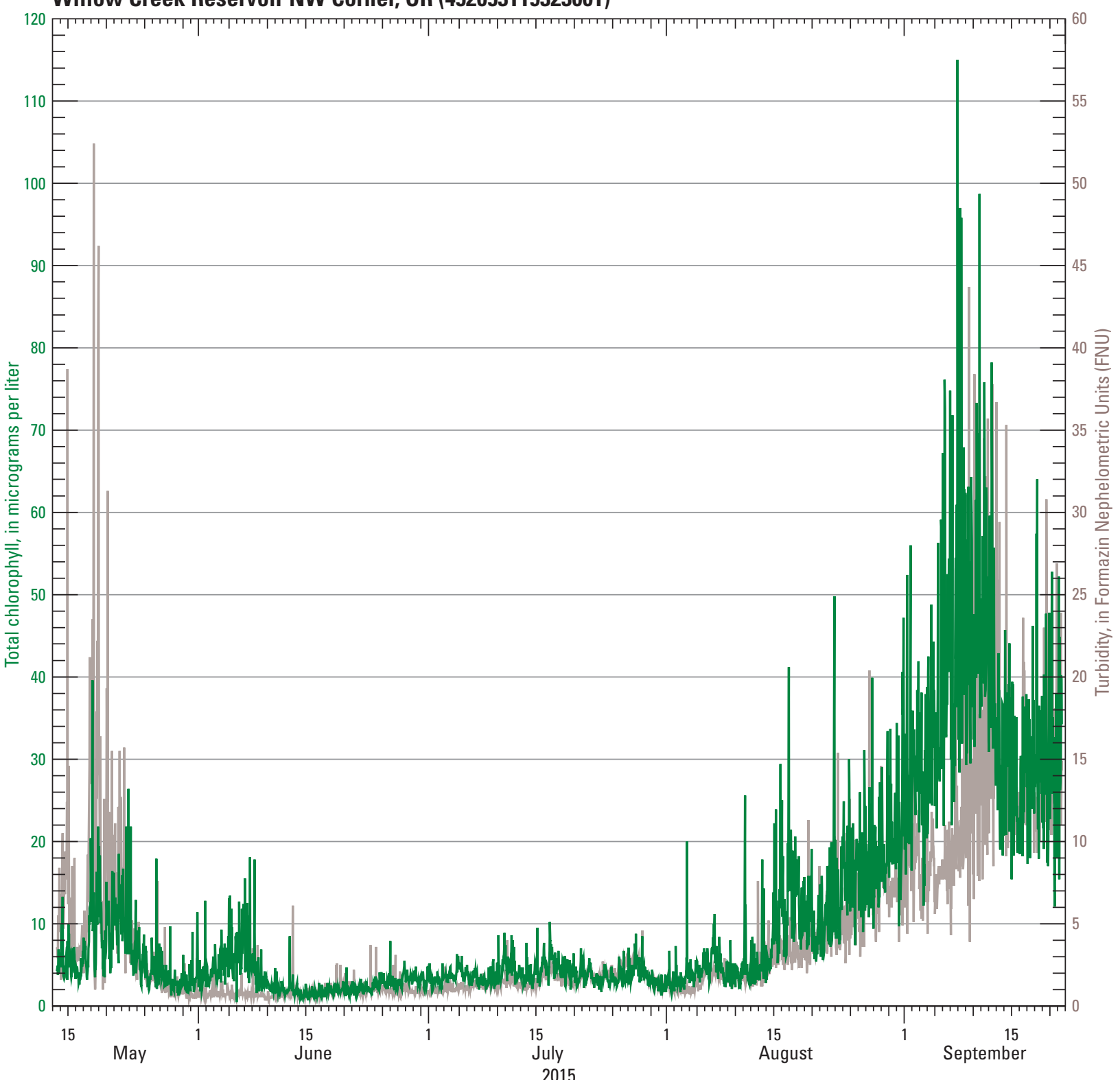

Figure 5. Hourly total chlorophyll ( $\mu \mathrm{g} / \mathrm{L})$ and turbidity (FNU) data during May-September 2015 at the fixed location in the northwestern corner of Willow Creek Reservoir, north-central Oregon (U.S. Geological Survey, 2018b). 
Willow Creek Reservoir NW Corner, OR (452053119323001)

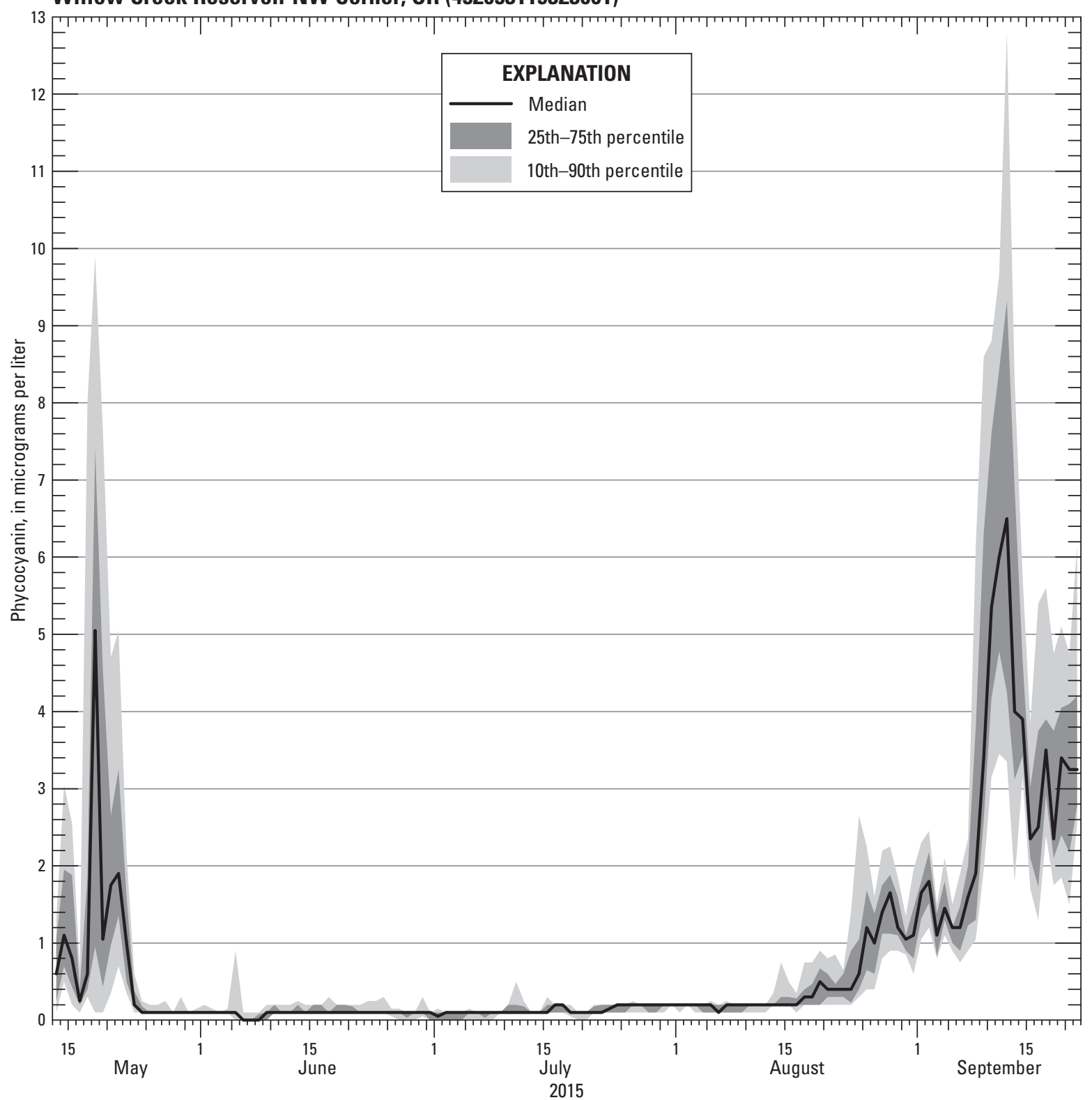

Figure 6. Median, 10th-90th percentiles, and the 25th-75th percentiles for blue-green algae-phycocyanin data collected during May-September 2015 at the fixed location in the northwestern corner of Willow Creek Reservoir, north-central Oregon (U.S. Geological Survey, 2018b). 


\section{Camera Monitoring Results}

All camera images from 2015 and 2016 are archived in Smith (2017a). Monitoring surface blooms with a camera revealed that surface accumulations in this reservoir have the capacity to form and dissipate within 15 minutes based on wind and currents (fig. 7). In 2015, the camera was functioning and saved images on 106 of 180 days that the camera was deployed. The 74 days of missing images were a result of technical issues caused by faulty charge controllers for the solar panel. During the 2016 deployment, images were telemetered on 108 of 126 days. The 18 days of missing images were due to poor cellular coverage; consistent telemetry began in September 2016 when the cellular company, modem, and antenna were replaced.

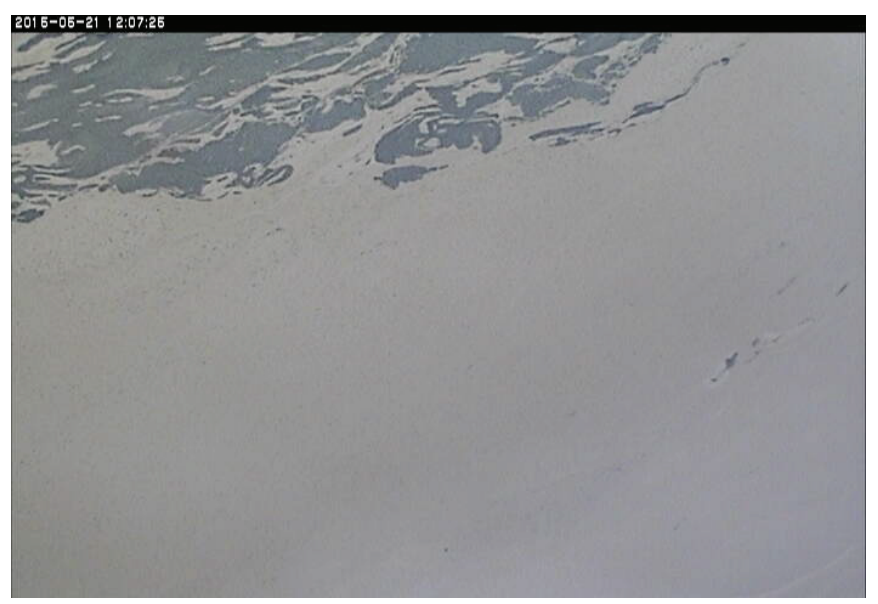

The proof-of-concept camera monitoring study demonstrated that cyanobacterial surface blooms were visible in images from a color surveillance camera. Successive images could be joined together to view a video of the bloom on a given day. Not all images were clear or useful, and figure 8 shows a variety of images from the 2015 and 2016 field seasons. The use of a polarizing lens during this study was unnecessary and caused the cyanobacterial blooms to appear light brown. Collecting high-frequency images was advantageous considering that some images were obscured by glare or cloud reflection. Telemetering images from Willow Creek Reservoir was successful, and images could be viewed in near-real time by the resource managers (fig. 9).

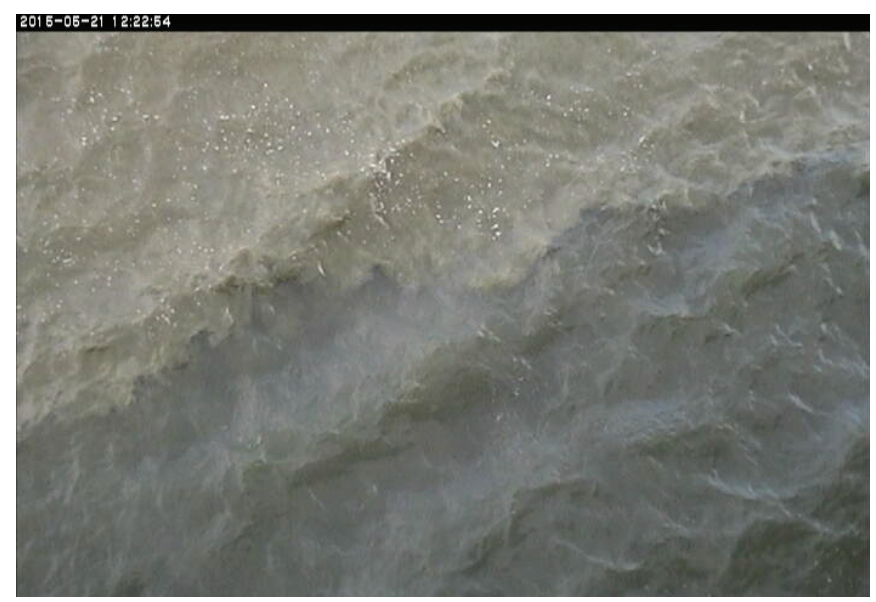

Figure 7. Two images of a cyanobacterial bloom in Willow Creek Reservoir taken 15 minutes apart from the same position on May 21, 2015. The image on the left shows a surface accumulation, which is the lighter color and covering about three-quarters of the image. The image on the right shows the bloom mixed in the water. The blooms appear brown because the camera was temporarily outfitted with a polarizing lens. Photographs by U.S. Geological Survey. 


\section{Polarizing lens}

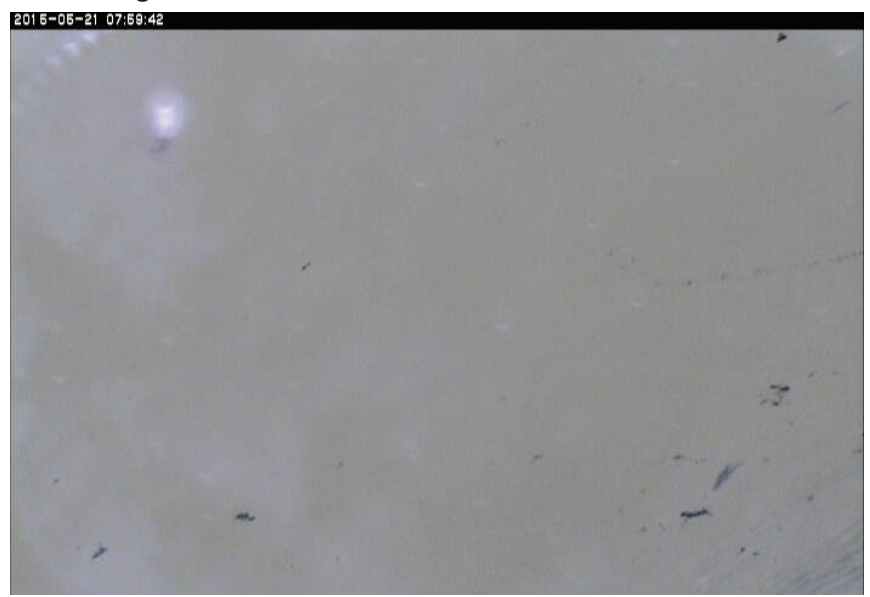

Glare

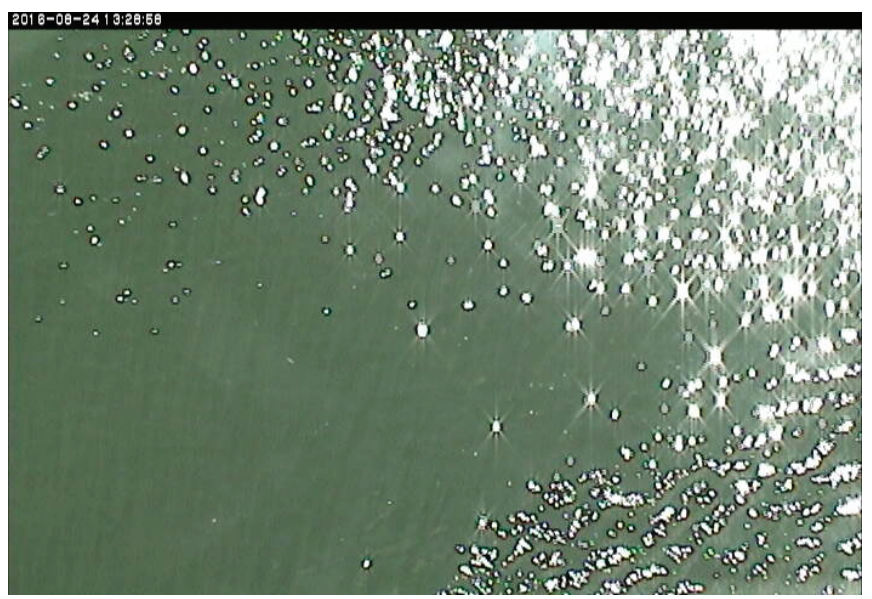

\section{Reflection}

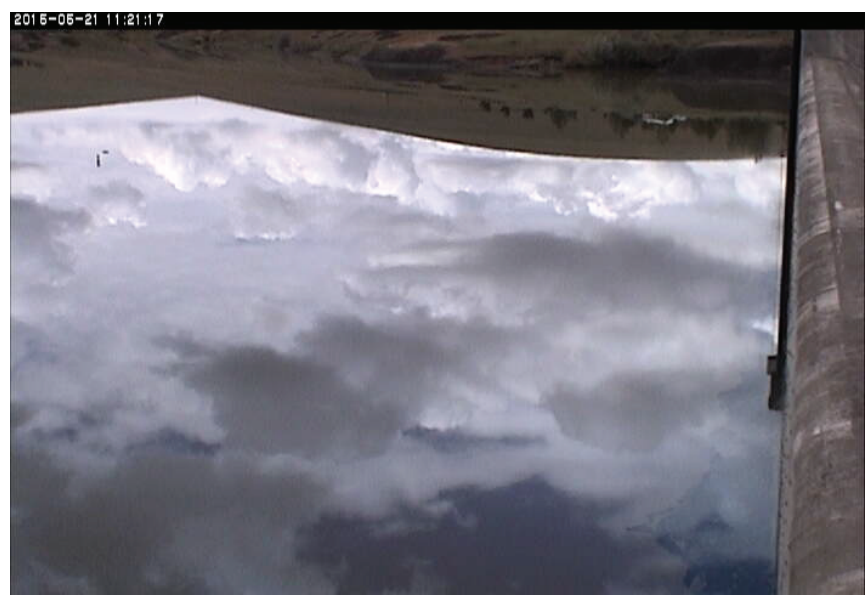

Desired outcome

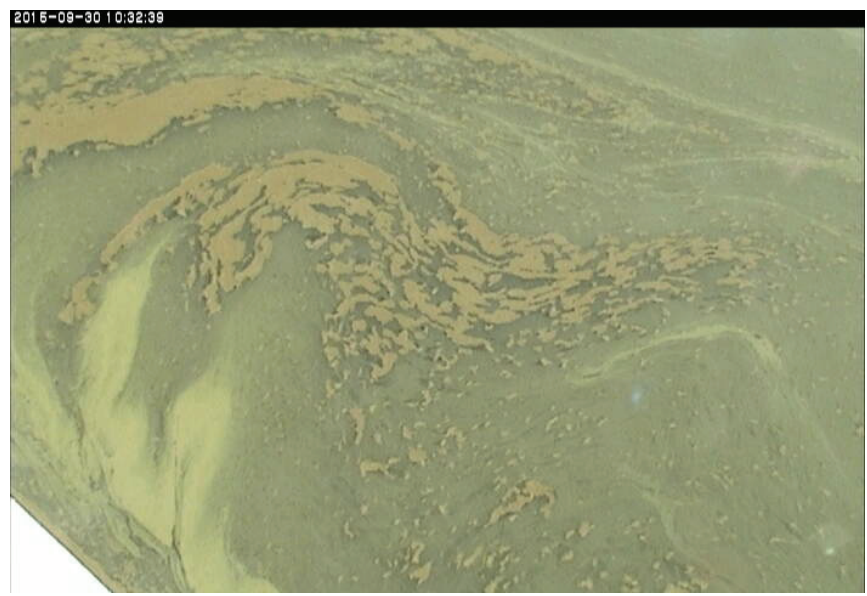

Figure 8. Images taken by the Axis 214 camera in the northwestern corner of Willow Creek Reservoir, north-central Oregon, showing four types of image quality. The top left panel shows a complete covering of a cyanobacterial surface scum that appears brown due to the polarizing lens. The top right panel and the bottom left panel are examples of interference from cloud reflection and glare. The bottom right image captures a cyanobacterial bloom in the northwestern corner of the reservoir without the use of a polarizing lens. Photographs by U.S. Geological Survey. 


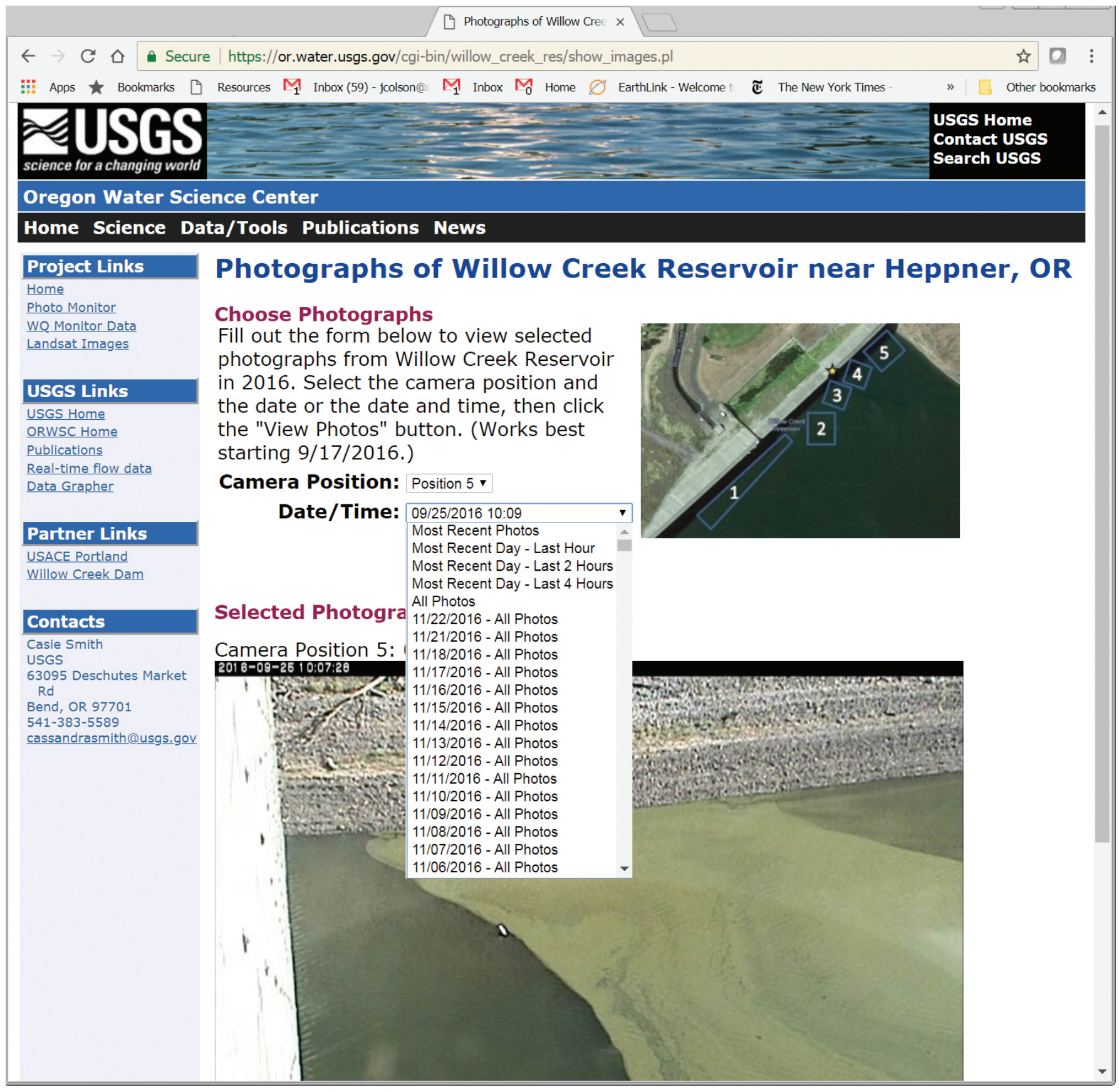

Figure 9. Images taken by the Axis 214 camera in the northwestern corner of Willow Creek Reservoir, north-central Oregon, showing functionality of website. Images of the surface of the water were taken at five positions every 15 minutes during daylight hours.

During 2016, the images were telemetered to a website in near real-time. This figure displays the functionality of the website that was available to both researchers and resource managers. 


\section{Camera and Instrument Results}

Comparing the camera and water-quality instrument results indicated that the findings generally supported each other, but that differences in surface and water column conditions did occur. Images from May 14 through June 26, 2015, were visually inspected for the presence of a surface bloom accumulation, and camera images showed surface blooms during a total of 200 daylight hours of that period. The continuous water-quality data were collected from $1.5 \mathrm{ft}$ below the surface of the water, and figure 10 displays the hourly visual bloom occurrences overlaid with the continuous total chlorophyll data from the same period.

The elevated total chlorophyll data indicated when bloom conditions were measured with the water-quality instrument. Similar trends and timing were observed in the $\mathrm{pH}$, dissolved oxygen, turbidity, and BGA-PC data. There were a few hours in June where surface accumulations were observed in images, but no elevated response was detected by the total chlorophyll probe (fig. 10). The ephemeral surface accumulations observed on June 14, June 21, and June 26, 2015, appeared in the early morning; it is possible that those films were not comprised of cyanobacteria and were possibly pollen. Conversely, the water-quality instrument measured relatively high total chlorophyll in early June that was not detected by the camera.

\section{Spatial Mapping Results}

All data from the three spatial mapping events are archived in Smith (2017b). A period of low algal activity was observed during the mapping event conducted from 1103 to 1245 PDT on June 9, 2015; the LandSat 8 image and the color surveillance camera images (not shown) confirm that the reservoir did not have high algal productivity or a cyanobacterial surface accumulation at that time. Dissolvedoxygen measurements ranged from 109.2 to 115.0 percent saturation, and the EXO2 total chlorophyll readings ranged from 0.4 to $1.2 \mu \mathrm{g} / \mathrm{L}$. The stationary, continuous water-quality instrument logged similar readings as were collected from the mapping effort (table 2).

During the mapping event on August 17, 2016 (from 1305 to 1430 PDT), water appeared green and possible Aphanizomenon filaments were observed, but no surface bloom was present. Dissolved-oxygen measurements reached 155.8 percent saturation and $\mathrm{pH}$ reached 9.15 standard units, which are indicative of high levels of algal activity. Most of the total chlorophyll readings were low $(<1 \mu \mathrm{g} / \mathrm{L})$, but elevated total chlorophyll readings (maximum of $34.8 \mu \mathrm{g} / \mathrm{L}$ ) were detected in a small area in the Balm Fork arm of the reservoir.

Table 2. Comparison of the YSI EXO2 multi-parameter water-quality readings measured at the same location in Willow Creek Reservoir, north-central Oregon, June 9, 2015.

[Instrument readings: Stationary, continuous instrument logged hourly, while the spatial mapping instrument was secured to a moving boat and logged every 10 seconds. Both instruments were 1.5 feet ( 0.5 meter) below the surface of the water. Total chlorophyll values are raw values, not corrected to discrete samples. YSI, Yellow Spring Instrument]

\begin{tabular}{lcc}
\hline \multirow{2}{*}{ Parameter } & \multicolumn{2}{c}{ Instrument readings } \\
\cline { 2 - 3 } & $\begin{array}{c}\text { Spatial mapping } \\
\text { (recorded at 1140 PDT) }\end{array}$ & $\begin{array}{c}\text { Stationary, continuous } \\
\text { (recorded at 1200 PDT) }\end{array}$ \\
\hline Water temperature (degrees Celsius) & 24.23 & 24.02 \\
Specific conductance (microsiemens per centimeter) & 229.6 & 228.0 \\
pH (standard units) & 8.93 & 8.93 \\
Dissolved oxygen (milligrams per liter) & 9.17 & 9.40 \\
Turbidity (Formazin Nephlometric Units) & 0.52 & 0.60 \\
Chlorophyll, total (micrograms per liter) & 0.49 & 0.48 \\
Blue-green algae-phycocyanin (micrograms per liter) & 0.12 & 0.11 \\
\hline
\end{tabular}



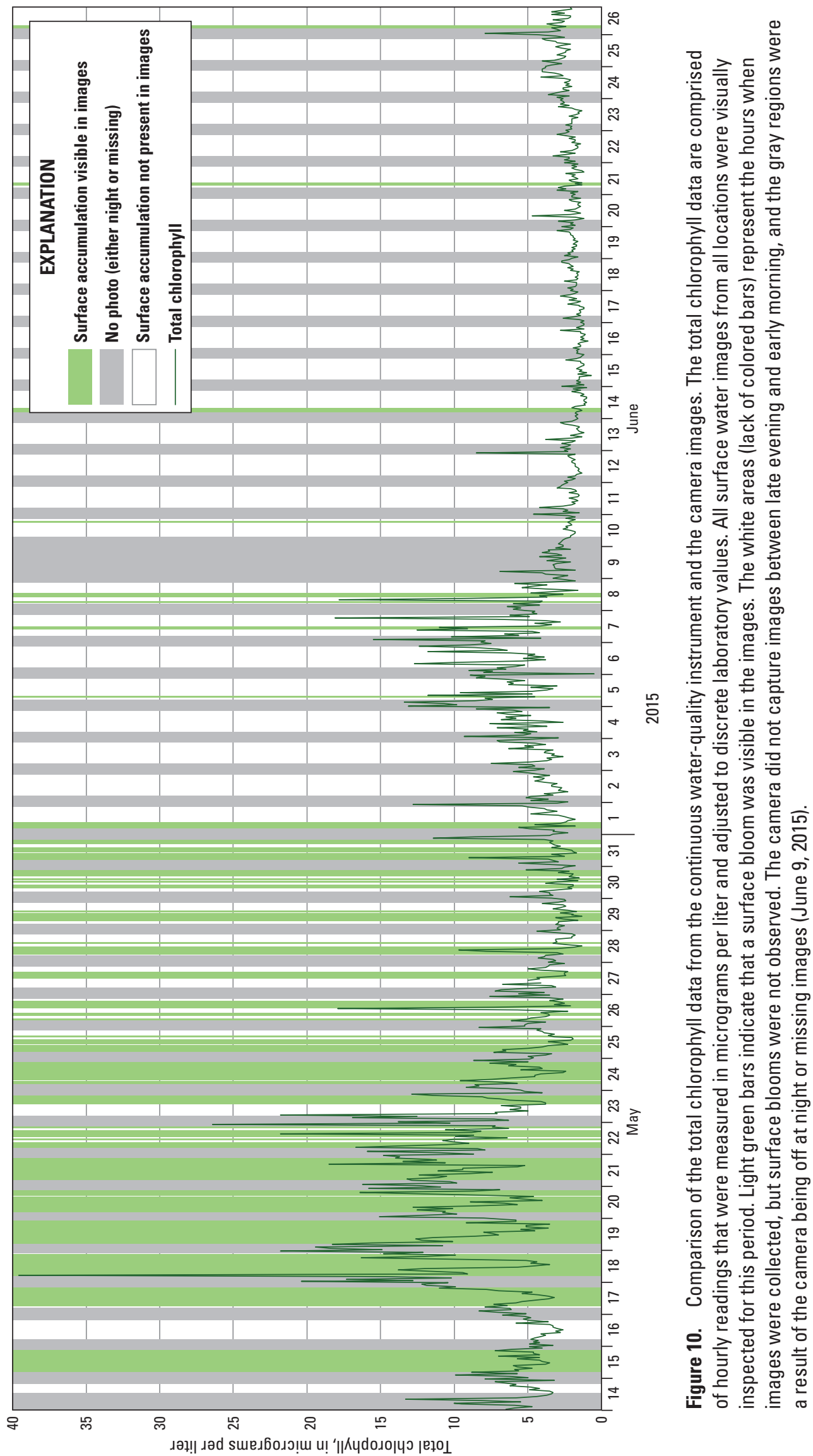
A surface bloom was present in the northwestern corner of the reservoir during the mapping event that took place from 1150 to 1400 PDT on September 16, 2016. Measured dissolved oxygen reached a maximum of 121.6 percent saturation while total chlorophyll readings reached a maximum of $4.9 \mu \mathrm{g} / \mathrm{L}$ (fig. 11). Instrument readings were assigned to the closest corresponding GPS coordinate reading in time. Data were analyzed in ArcGIS using the Inverse Distance Weighted spatial analyst tool to create colorized maps that represent how the water quality varied spatially in the reservoir. A water temperature map from September 16, 2016 (fig. 12) reveals warmer water along the southern edges of the reservoir (within the Balm Fork arm) and along the face of the dam. The dissolved oxygen map from that date shows higher oxygen percent saturation in areas with warmer temperatures, indicating that more algal productivity is occurring in these areas. The total chlorophyll and BGA-PC trends provided supporting evidence for what was observed in the other parameters but were not conclusive as stand-alone maps, likely due to overall low concentrations (figs. 11 and 13). Spatial turbidity data from September 16 also supported the evidence that the Balm Fork arm of the reservoir had higher algal productivity than other areas of the reservoir. Analyzing maps of multiple water-quality parameters provides a more complete understanding of spatial variation than any one parameter.

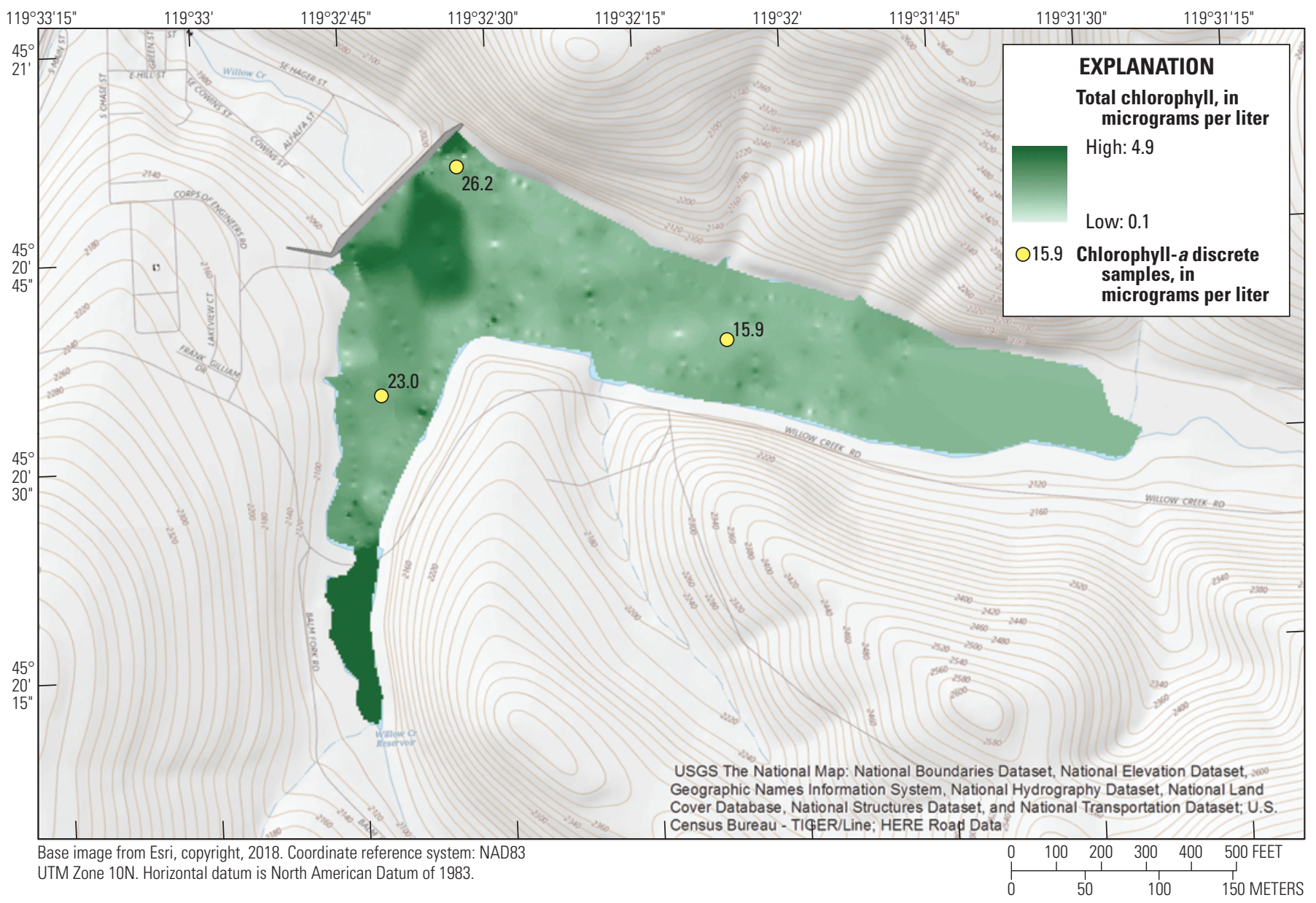

Figure 11. A colorized map representing relative total chlorophyll concentrations throughout the reservoir at 1.5 feet deep on September 16, 2016, from 1150 and 1400 PDT. Data for the colorized map were derived from boat transects as shown in figure 3. Data were analyzed in ArcGIS using the Inverse Distance Weighted spatial analyst tool. Areas that were too shallow for the boat to sample were interpreted based on the nearest measurements. Discrete water samples were collected from the three noted locations as soon as the mapping was complete, and samples were analyzed in the USGS Oregon Water Science Center laboratory following EPA Method 445.0 In Vitro Determination of Chlorophyll a. Mapping data were not corrected to laboratory results. 


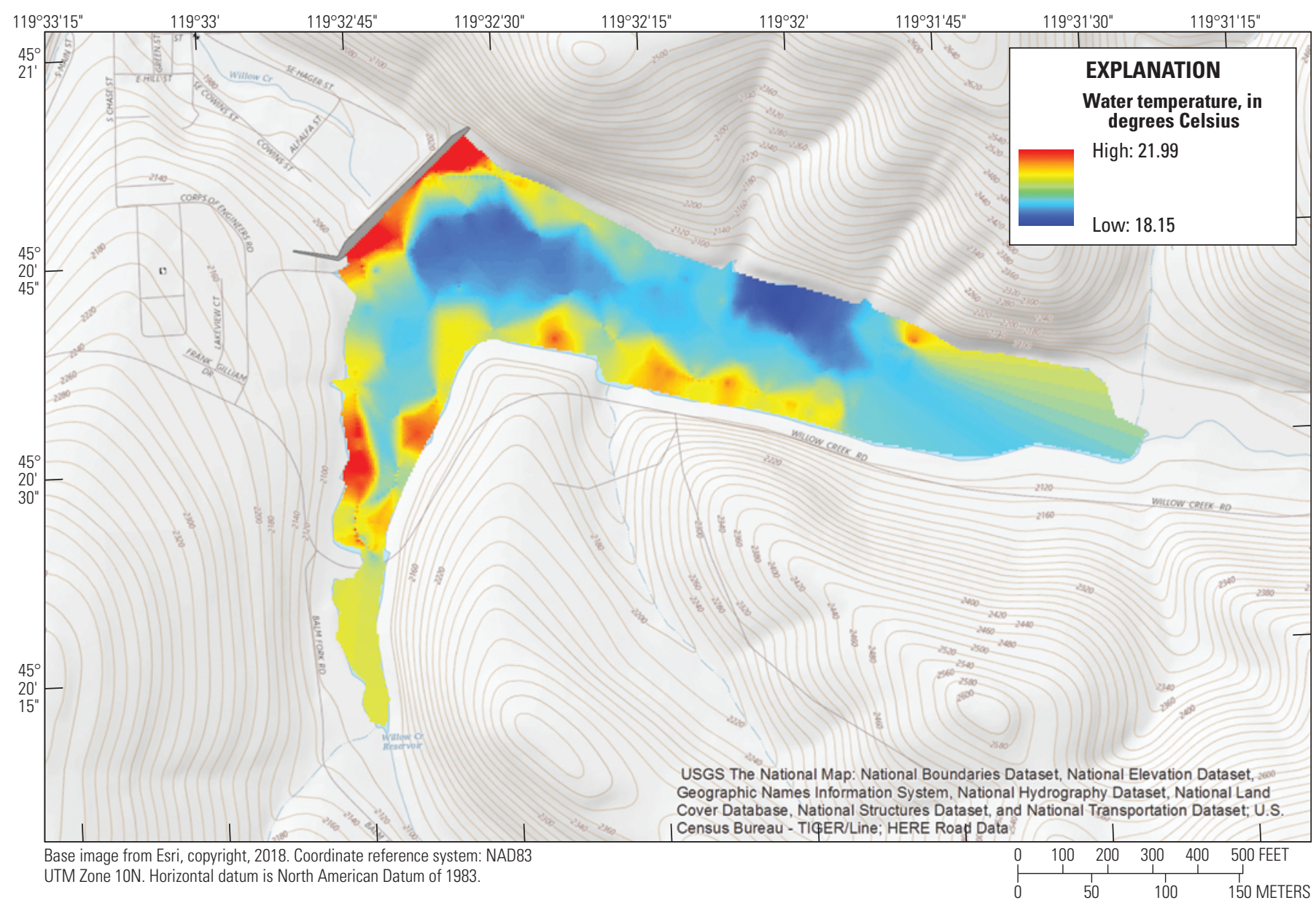

Figure 12. A colorized map representing water temperature throughout the reservoir at 1.5 feet deep on September 16, 2016, from 1150 to 1400 PDT. Data for the colorized map were derived from boat transects as shown in figure 3. Data were analyzed in ArcGIS using the Inverse Distance Weighted spatial analyst tool. Areas that were too shallow for the boat to sample were interpreted based on the nearest measurements. 


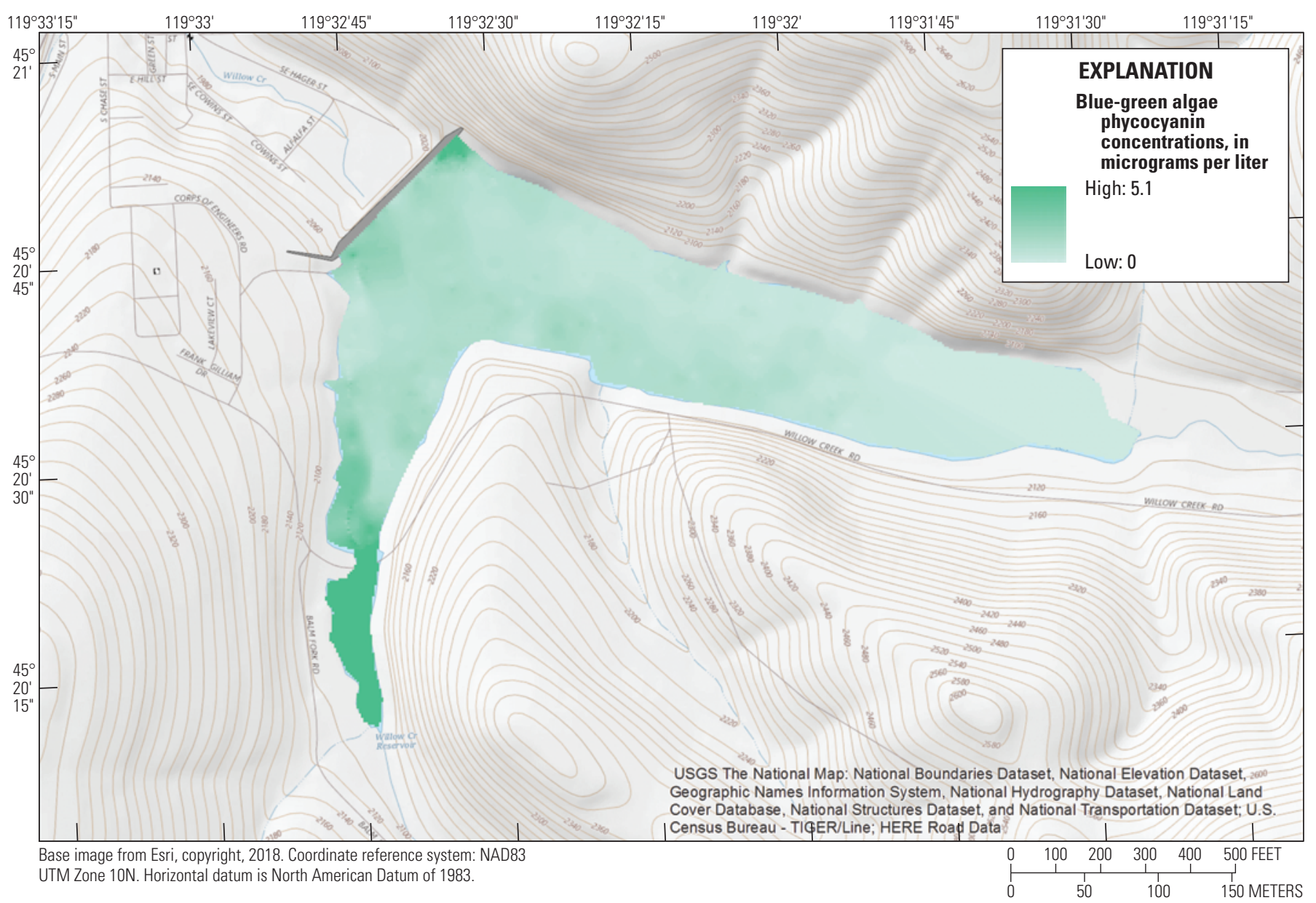

Figure 13. A colorized map representing relative blue-green algae-phycocyanin concentrations throughout the reservoir at 1.5 feet deep on September 16, 2016, from 1150 and 1400 PDT. Data for the colorized map were derived from boat transects as shown in figure 3. Data were analyzed in ArcGIS using the Inverse Distance Weighted spatial analyst tool. Areas that were too shallow for the boat to sample were interpreted based on the nearest measurements.

\section{Temporal and Spatial Monitoring of Cyanobacterial Blooms}

Each monitoring method tested (camera, in-situ multiparameter instrument, spatial mapping) in 2015 and 2016 at Willow Creek Reservoir was successfully used to collect valuable information. However, each method has benefits and limitations, and determining which equipment and method to use should be based on the resource managers' goals and how the information will be used. Ultimately, the combination of all three methods helped provide details on timing, severity, spatial extent, and capacity for early warning that no single method would deliver.
One objective of this study was to evaluate multiple monitoring devices, including the color surveillance camera and the multi-parameter water-quality instrument. The camera was deployed for approximately 8 months from 2015 to 2016 and collected information about cyanobacterial surface bloom dynamics, including duration and frequency. Standard tools previously used to monitor blooms in the reservoir include analyzing routine samples (collected about once every 2 weeks) or viewing LandSat8 images (taken once every 16 days). With images of the reservoir captured every 15 minutes, the camera collected more thorough temporal coverage than the other data-collection methods could provide. The camera revealed that the presence of surface bloom scums or accumulations can change rapidly 
(on the order of 15 minutes or less) due to a wind mixing effect, which could help inform routine toxin sampling and recreation. Other benefits of deploying a camera include the relatively inexpensive equipment costs and the ability to use the equipment for multiple seasons. Technology has improved since the Axis 214 camera (used in this study) went on the market, and using a modern color surveillance camera would provide higher color resolution and improve this collection technique. Limitations of monitoring with a camera in a remote location include the potentially poor cellular coverage for telemetry and the challenging logistics associated with positioning the camera above the water at the proper angle. While the camera could pan and capture images from multiple angles, the spatial coverage of the camera was limited and multiple cameras may be required for larger reservoirs. In areas of poor cellular coverage, telemetry via an alternate cabled Internet connection may be needed.
Once the telemetry was established, the camera provided near real-time color images of the surface of the remote reservoir via a website interface to resource managers who were located about $200 \mathrm{mi}$ away (fig. 9). Images may provide more useful information to the public than other types of data because images require minimal interpretation. Telemetered images could be made available to the public to inform their decisions about fishing and safe recreation (figs. 14-17). Additionally, telemetered images could be used as an early warning system that could prompt resource managers to collect samples for toxin analysis and to potentially issue recreational closures. In the future, the camera method could be adapted to utilize pigment-detecting software to automate the process and alert resource managers when a pigment concentration threshold is exceeded.

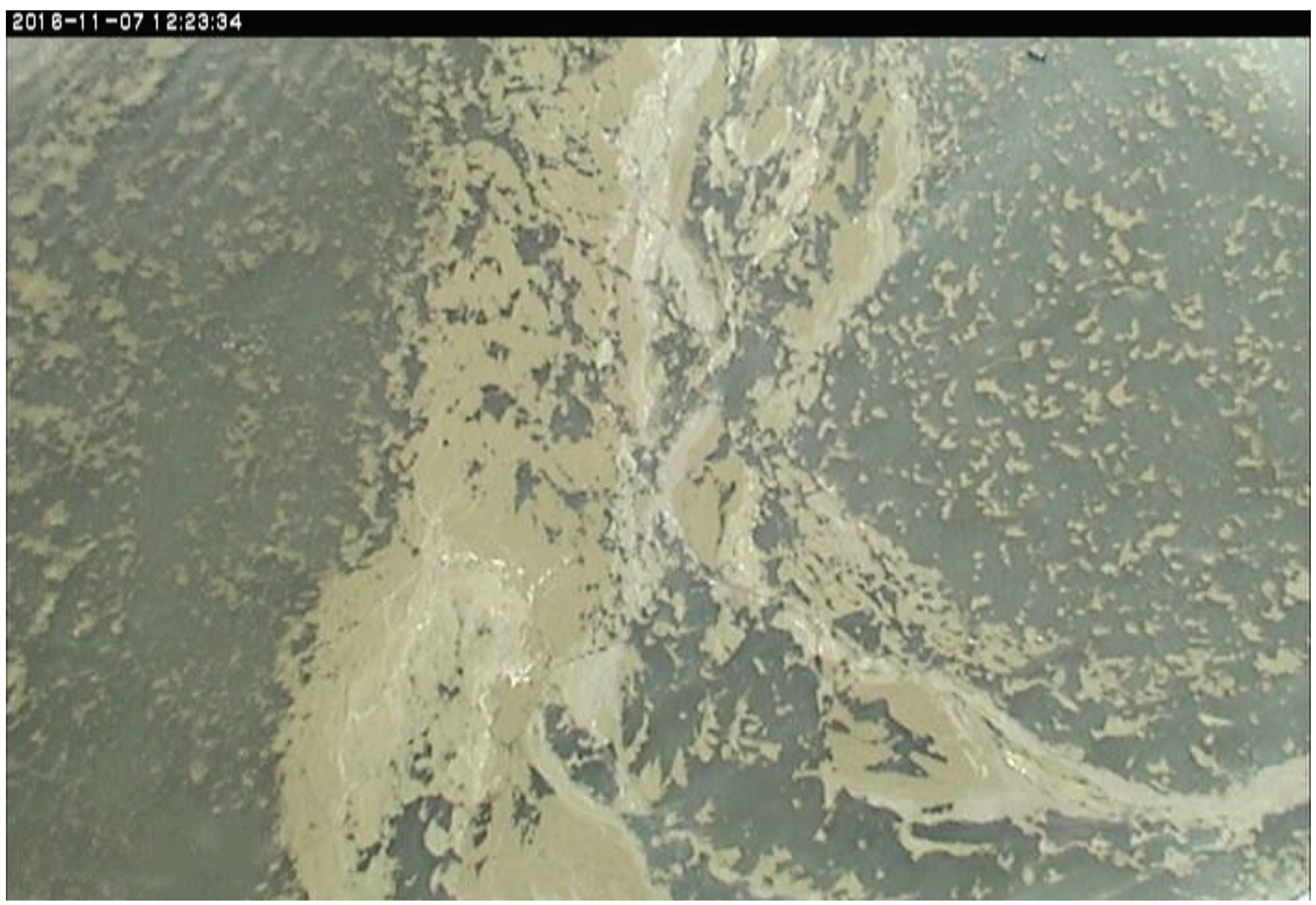

Figure 14. An algal surface accumulation occurring in the northwestern corner of Willow Creek Reservoir, north-central, Oregon, November 7, 2016, at 1223 PST. Photograph by U.S. Geological Survey. 


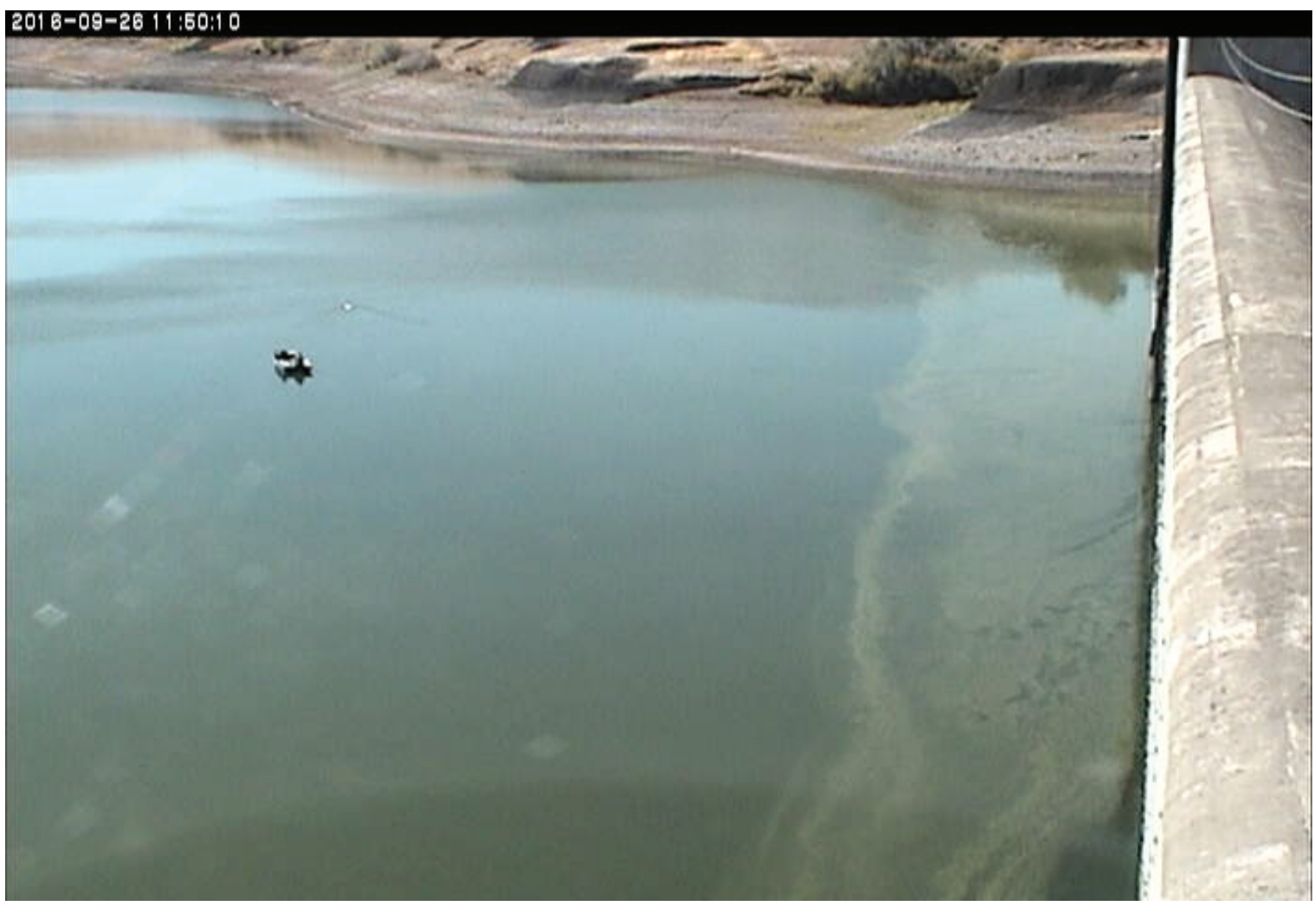

Figure 15. An algal bloom occurring along the dam face in Willow Creek Reservoir, north-central Oregon, September 26, 2016, at 1150 PDT. Photograph by U.S. Geological Survey.

Another objective of the study was to monitor the effects of cyanobacterial blooms on the reservoir's water quality. During the 4 months that the continuous instrument was deployed in Willow Creek Reservoir, 17.5 percent of the values exceeded the Total Maximum Daily Load (TMDL) maximum limit of 9.0 standard units (Oregon Department of Environmental Quality, 2017), and the $\mathrm{pH}$ reached a maximum of 9.5 standard units. Those $\mathrm{pH}$ values are biologically relevant because such basic $\mathrm{pH}$ values can cause ammonia in the water column to remain in its un-ionized form, which can negatively affect fish gills and ultimately cause ammonia toxicity if concentrations are high enough (U.S. Environmental Protection Agency, 2013). The water-quality instrument data also revealed supportive trends among total chlorophyll, turbidity, and BGA-PC, and more information can be gleaned from these datasets. For example, with additional data and the development of a model, turbidity might become a suitable surrogate for total phosphorus concentrations in the reservoir. Stone and others (2013) developed a model using dissolved oxygen, specific conductance, and fluorescence data to obtain estimates of dissolved phosphorus concentrations in a reservoir in Kansas. These types of models may allow the inference of continuous nutrient concentrations that could help elucidate nutrient loading patterns and ultimately assist in controlling algal blooms.

Continuous water-quality monitoring is often viewed as an expensive form of data collection because the instruments require ongoing maintenance and the data require auditing or adjusting (based on calibration and fouling corrections) to ensure their accuracy; however, numerous benefits can be derived from collecting multiple years of continuous data from an impaired water body. Continuous monitoring collects data during short-term events, when manual on-site sampling may not be possible, and helps define baseline conditions. Studying the baseline conditions will provide possible benchmarks, or goals, for restoration practices in the future. The continuous 


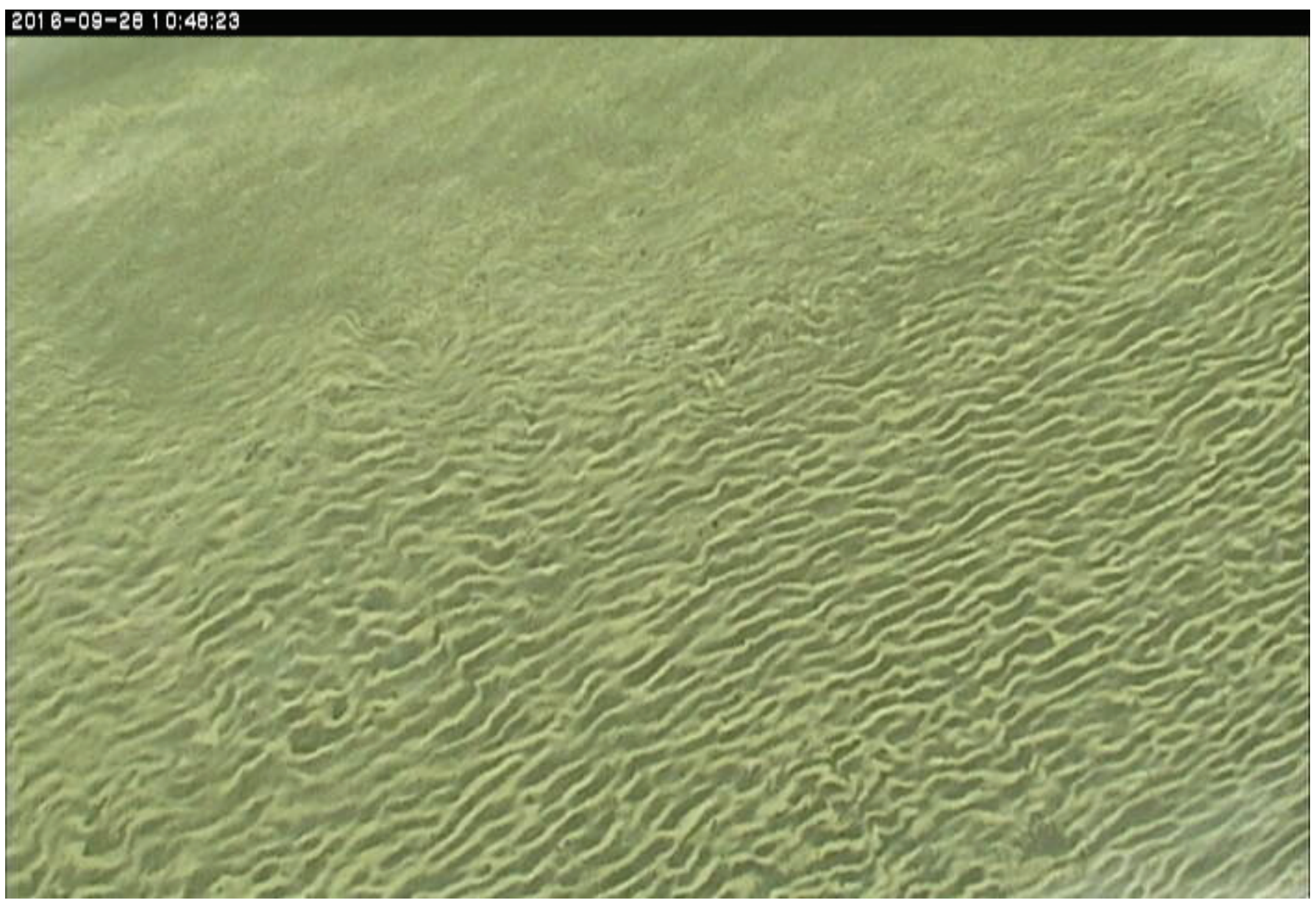

Figure 16. An algal surface accumulation occurring in the northwestern corner of Willow Creek Reservoir, north-central Oregon, September 28, 2016, at 1048 PDT. Photograph by U.S. Geological Survey.

water-quality data were collected in 2015, which was a notably drier- and warmer-than-normal summer in Oregon (National Oceanic and Atmospheric Administration, 2015a, 2015b, 2015c). Multiple years of continuous water-quality monitoring will reduce the effects of outlier years. Continuous water-quality data also provide information regarding the magnitude, duration, and frequency of the impaired water conditions, which could be useful when determining if any TMDL regulations are exceeded. It is important to note that the instrument measurements were taken from only one point and one depth in the reservoir. These values may not represent the conditions in other parts of the reservoir and extrapolation is unlikely to provide accurate information, as shown by Foster and others (2017).
The continuous water-quality data show that two distinct bloom events occurred during 2015, in May and August/ September. During both events, the magnitude of maximum physicochemical values and their diurnal variability were higher compared to non-bloom periods (fig. 6). Water-quality parameters measured in July (between bloom events) are suitable reference conditions, and were generally low (total chlorophyll: $\leq 10 \mu \mathrm{g} / \mathrm{L} ;$ BGA: $<1 \mu \mathrm{g} / \mathrm{L} ;$ DO: $\leq 9.5 \mathrm{mg} / \mathrm{L}$; $\mathrm{pH}: \leq 9.0$ standard units) with a minimal 10-day mean diurnal variation (total chlorophyll: $4 \mu \mathrm{g} / \mathrm{L}$; BGA-PC: $0.4 \mu \mathrm{g} / \mathrm{L}$; DO: $0.4 \mathrm{mg} / \mathrm{L}$; pH: 0.03 standard units). The May bloom event was characterized by a maximum chlorophyll and BGA-PC concentration of 39.6 and $15.2 \mu \mathrm{g} / \mathrm{L}$, respectively. 


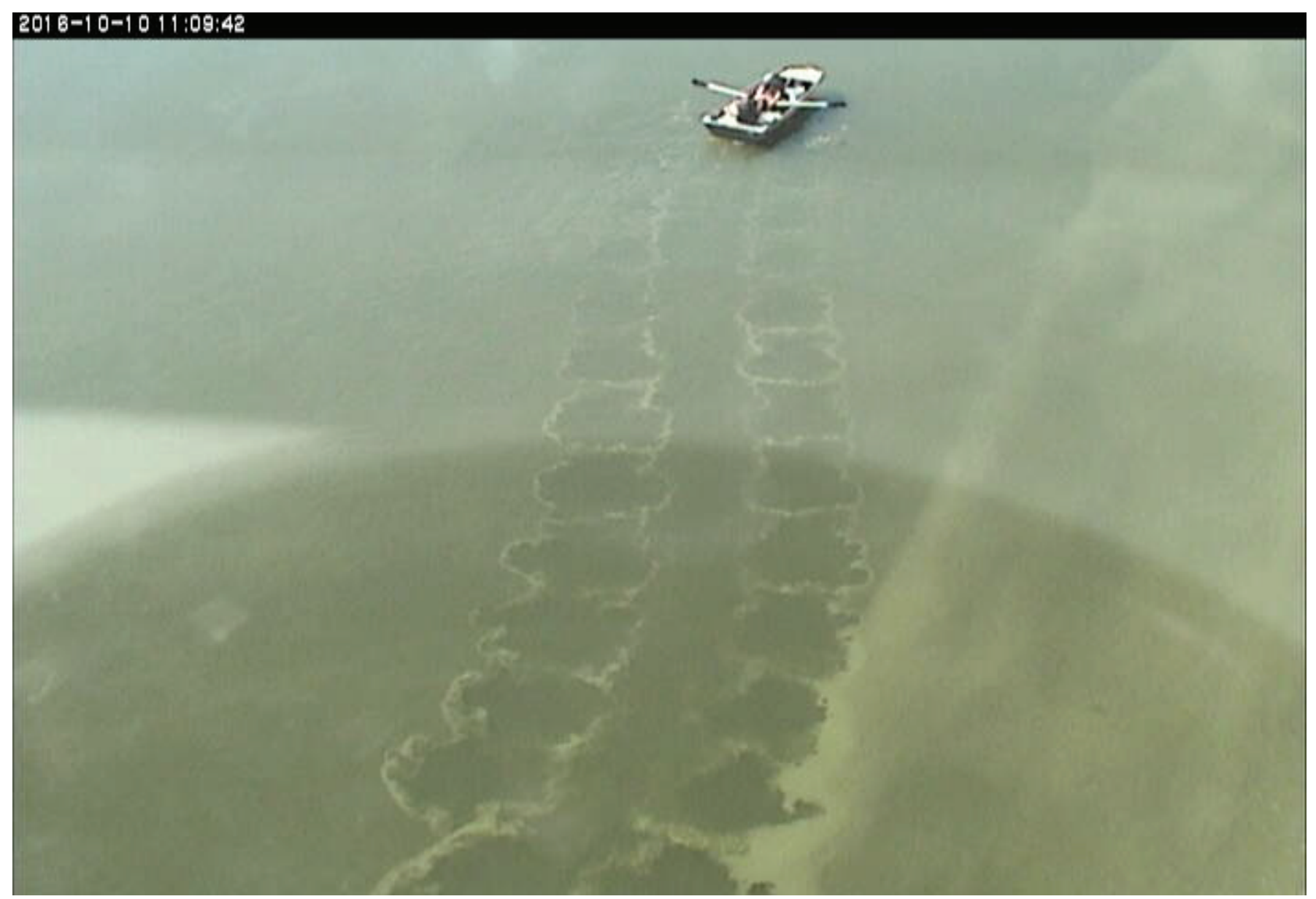

Figure 17. A boat paddles through an algal bloom occurring in the northwestern corner of Willow Creek Reservoir, north-central Oregon, October 10, 2016, at 1109 PDT. Photograph by U.S. Geological Survey.

The dissolved oxygen and $\mathrm{pH}$ were relatively elevated (DO maximum= $12.3 \mathrm{mg} / \mathrm{L}$; $\mathrm{pH}$ maximum=9.1 standard units) and dissolved oxygen 10-day mean diurnal variability was twice as high as reference conditions in July. Chlorophyll and BGA-PC concentrations during the August/September bloom event reached 115.0 and $20.8 \mu \mathrm{g} / \mathrm{L}$, respectively. The dissolved oxygen and $\mathrm{pH}$ values and trends appeared to have been tightly coupled with the algal biomass production during the August/September bloom; the dissolved oxygen reached $18.5 \mathrm{mg} / \mathrm{L}$ and diurnal variability was 7.5 times higher than the reference conditions in July. A greater response of the water-quality parameters occurred for the August/September bloom than for the May bloom. One potential explanation for the more pronounced water-quality effects during the August/September bloom is that water temperature was warmer than in May and may have created more favorable conditions. Secondly, laboratory identification determined that the phytoplankton communities differed between the May and August/September blooms. Although Dolichospermum was a dominant genus in both blooms, Aphanizomenon was also considered dominant in the August/September bloom, indicating that Aphanizomenon may have a stronger influence on water quality. Increased variability of chlorophyll, BGA-PC, dissolved oxygen, and $\mathrm{pH}$ can indicate that ecosystem changes are occurring (Batt and others, 2013), and analyzing trend variability can be useful when monitoring and identifying blooms.

Comparing the camera images to the trend of total chlorophyll concentrations (fig. 10) revealed that the two monitoring methods generally support each other. Chlorophyll concentrations were low (mostly $<25 \mu \mathrm{g} / \mathrm{L}$ ) in May 2015, even though bloom conditions were occurring. A sample collected in the northwestern corner on May 9, 2015, and analyzed by Green Water Laboratories in Palatka, Florida, 
revealed that microcystin concentrations were well below the State of Oregon's guidelines for recreational water. The results of these monitoring methods illustrate one of the challenges of monitoring and managing harmful algal blooms. In this case, algal biomass was present, chlorophyll and other parameters increased in magnitude and variability, but the point sample indicated that the toxins at the moment of sampling were below harmful thresholds. Conditions and biomass can change quickly, and toxin concentrations may have varied during the weeks that the surface accumulation was visible. This example emphasizes the value of applying multiple monitoring approaches.

While the continuous water-quality instrument measured high frequency data from one location, the spatial mapping assessed the heterogeneity of the water chemistry throughout the reservoir in a discrete time period. Table 2 shows similar measured values from the stationary instrument and the mapping instrument, indicating that the mapping effort collected valid measurements that were not affected by movement. The spatial mapping was conducted continuously, without pausing to collect discrete samples, to minimize the effects of changing environmental conditions on the water chemistry. Considering that the boat returned to specified locations to collect discrete samples after the mapping was complete, the discrete chlorophyll- $a$ results should be considered as approximate, or relative, values (fig. 11); mapping data were not corrected to laboratory results due to these limitations. EXO2 total chlorophyll probes provide relative values, emphasizing the importance of collecting and analyzing discrete samples.

Spatially mapping the body of water may reveal areas to focus restoration efforts and areas with high BGA-PC concentrations to sample for toxins (Foster and others, 2017; Graham and others, 2017). A surface bloom is present in images from September 16, 2016, and the instrument data support that a bloom was occurring in the northwestern corner of the reservoir. The general patterns of water quality documented on that date showed that the Balm Fork arm of the reservoir was one area that contained high temperatures, super-saturated dissolved oxygen, and relatively high total chlorophyll readings. Based on the mapping route and time of day, the observed patterns in the data were not a result of sampling bias due to diurnal fluctuations. The spatial mapping data were collected around mid-day for each of the three events; however, the dissolved oxygen and $\mathrm{pH}$ often peaked later in the afternoon in the reservoir. Conducting spatial mapping events at specific times would collect more targeted data, potentially including the extremes for a given day.

\section{Summary and Conclusions}

This study displayed the effectiveness of monitoring with multiple devices concurrently. The camera images capture surface blooms, but do not collect information regarding changes or conditions in the water column. The waterquality instrument collects high-frequency data from the water-column, but determining when a bloom begins or ends requires trend interpretation. This continuous dual monitoring method showed when a surface bloom initiated and dissipated and revealed the magnitude, or potential severity, of the impacts to the water quality. Monitoring with multiple instruments provided a more comprehensive dataset than any one monitoring method.

Identifying innovative and cost-effective monitoring approaches will become more essential as the frequency, duration, and intensity of cyanobacterial blooms increase, as predicted by Pearl and Huisman (2009). Currently, a lack of knowledge exists regarding the linkages between bloom occurrence and toxin production, and future research and monitoring that focuses on the relationships between water-quality parameters and toxin concentrations would improve the predictive and management value of such methods. Monitoring networks and spatial mapping could determine the extent, location, and frequency of affected areas during bloom events (Foster and others, 2017; Graham and others, 2017). Near real-time data may lead to abbreviated water-body closures, moderating economic damage due to loss of recreation and alleviating inconvenience to the public. Multiple years of data collection, along with local meteorological data, can be used to create predictive models for cyanobacterial blooms. Early warning systems and predictive models may be one way to minimize the risks of cyanobacterial blooms to recreational users of water bodies.

\section{Acknowledgments}

The author would like to thank staff at the U.S. Army Corps of Engineers for their support, access to Willow Creek Dam, and for helpful discussions, particularly Kathryn Tackley and Dan Turner. Fieldwork was successful due to the assistance of Dr. Frank Wilhelm and Sarah Burnet from the University of Idaho, as well as JoJo Mangano, David Piatt, and David Weathers from USGS. Mentorship and support were provided by Joe Rinella, Stewart Rounds, and Zach Freed of USGS. 


\section{References Cited}

Abrams, M.M., and Jarrell, W.M., 1995, Soil phosphorus as a potential non-point source for elevated stream phosphorus levels: Journal of Environmental Quality, v. 24, p. 132-138.

Anderson, D.M., Cembella, A.D., and Hallegraeff, G.M., 2012, Progress in understanding harmful algal blooms: Paradigm Shifts and New Technologies for Research, Monitoring, and Management, Annual Review of Marine Science, v. 4, p. 143-176.

Arar, E.J., and Collins, G.B., 1997, Method 445.0 in vitro determination of chlorophyll a and pheophytin a in marine and freshwater algae by fluorescence: U.S. Environmental Protection Agency, Washington, D.C.

Batt, R.D., Carpenter, S.R., Cole, J.J., Pace, M.L., and Johnson, R.A., 2013, Changes in ecosystem resilience detected in automated measures of ecosystem metabolism during a whole-lake manipulation: Proceedings of the National Academy of Sciences, v. 110, p. 17398-17403.

Briand, J.F., Jacquet, S., Bernard, C., and Humbert, J.F., 2003, Health hazards for terrestrial vertebrates from toxic cyanobacteria in surface water ecosystems: Veterinary Research, v. 34, p. 361-377.

Carlson, R.E., and Simpson, J., 1996, A coordinator's guide to volunteer lake monitoring methods: North American Lake Management Society, $92 \mathrm{p}$.

Carmichael, W.W., Azevedo, S.M.F.O., An, J.S., Molica, R.J.R., Jochimsen, E.M., Lau, S., Rinehart, K.L., Shaw, G.R., and Eaglesham, G.K., 2001, Human fatalities from cyanobacteria: Chemical and Biological Evidence for Cyanotoxins, Environmental Health Perspectives, v. 109, p. 663-668.

Chen, J., Xie, P., Li, L., and Xu, J., 2009, First identification of the hepatotoxic microcystins in the serum of a chronically exposed human population together with indication of hepatocellular damage: Toxicological Sciences, v. 108, p. 81-89.

Chorus, I., and Bartram, J., ed., 1999, Toxic cyanobacteria in water: A guide to their public health consequences, monitoring and management: Published by E \& FN Spon on behalf of World Health Organization, 416 p.

Falconer, I.R., 1991, Tumor promotion and liver injury caused by oral consumption of cyanobacteria: Environmental Toxicology and Water Quality, v. 6, no. 2, p. 177-184.

Falconer, I.R., and Humpage, A.R., 2005, Health risk assessment of cyanobacterial (blue-green algal) toxins in drinking water: International Journal of Environmental Research and Public Health, v. 2, p. 43-50.
Foster, G.M., Graham, J.L., Stiles, T.C., Boyer, M.G., King, L.R., and Loftin, K.A., 2017, Spatial variability of harmful algal blooms in Milford Lake, Kansas, July and August 2015: U.S. Geological Survey Scientific Investigations Report 2016-5168, 45 p.

Graham, J.L., Loftin, K.A., and Kamman, N., 2009, Monitoring recreational freshwaters: LakeLine, v. 29, p. 16-22.

Graham, J.L., Foster, G.M., Williams, T.J., Kramer, A.R., and Harris, T.D., 2017, Occurrence of cyanobacteria, microcystin, and taste-and-odor compounds in Cheney Reservoir, Kansas, 2001-16: U.S. Geological Survey Scientific Investigations Report 2017-5016, 57 p.

Harris, T.D., Wilhelm, F.M., Graham, J.L., and Loftin, K.A., 2014, Experimental manipulation of TN:TP ratios suppress cyanobacterial biovolume and microcystin concentration in large-scale in situ mesocosms: Lake and Reservoir Management, v. 30, p. 72-83.

Jöhnk, K.D., Huisman, J., Sharples, J., Sommeijer, B., Visser, P.M., and Stroom, J.M., 2008, Summer heatwaves promote blooms of harmful cyanobacteria: Global Change Biology, v. 14, p. 495-512.

Kanoshina, I., Lips, U., and Leppänen, J., 2003, The influence of weather conditions (temperature and wind) on cyanobacterial bloom development in the Gulf of Finland (Baltic Sea): Harmful Algae, v. 2, p. 29-41.

Larson, D.W., 1997, Willow Creek Lake Oregon Limnological and Water-Quality Studies 1984-1996 Final Report: Douglas W. Larson Department of Biology Portland State University, $240 \mathrm{p}$.

Maberly, S.C., 1996, Diel, episodic and seasonal changes in $\mathrm{pH}$ and concentrations of inorganic carbon in a productive lake: Freshwater Biology, v. 35, p. 579-598.

National Oceanic and Atmospheric Administration, 2015a, National Centers for Environmental Information, State of the Climate: Synoptic Discussion for June 2015, accessed January 3, 2018, at https://www.ncdc.noaa.gov/sotc/ synoptic/201506.

National Oceanic and Atmospheric Administration, 2015b, National Centers for Environmental Information, State of the Climate: Synoptic Discussion for July 2015, accessed January 3, 2018, at https://www.ncdc.noaa.gov/sotc/ synoptic/201507.

National Oceanic and Atmospheric Administration, 2015c, National Centers for Environmental Information, State of the Climate: Synoptic Discussion for August 2015, accessed January 3, 2018, at https://www.ncdc.noaa.gov/sotc/ synoptic/201508. 
Oregon Department of Environmental Quality, 2017, Willow Creek Subbasin: DEQ’s Water Quality Status and Trends Analysis for the Oregon Department of Agriculture's Biennial Review of the Agricultural Area Rules and Plans, 47 p., accessed February 26, 2018, at http://www.oregon.gov/deq/ FilterDocs/willowStatusTrends.pdf.

Oregon Health Authority, 2016, Oregon Harmful Algae Bloom Surveillance (HABS) Program Sampling Guidelines: Cyanobacterial Harmful Blooms in Recreational Waters: Oregon Health Authority, 15 p., accessed December 5, 2017, at http://www.oregon.gov/ oha/PH/HEALTHYENVIRONMENTS/RECREATION/ HARMFULALGAEBLOOMS/Documents/HABs\%20 Sampling\%20Guidelines.pdf.

Paerl, H.W., Hall, N.S., and Calandrino, E.S., 2011, Controlling harmful cyanobacterial blooms in a world experiencing anthropogenic and climatic-induced change: Science of the Total Environment, v. 409, p. 1739-1745.

Paerl, H.W., and Huisman, J., 2008, Blooms like it hot: Science, v. 320, p. 57-58.

Paerl, H.W., and Huisman, J., 2009, Climate change: a catalyst for global expansion of harmful cyanobacterial blooms: Environmental Microbiology Reports, v. 1, p. 27-37.

Porder, S., and Ramachandran, S., 2012, The phosphorus concentration of common rocks - a potential driver of ecosystem P status: Plant Soil, 15 p., accessed December 5, 2017, at DOI 10.1007/s11104-012-1490-2.

Sadar, M.J., 1998, Turbidity Science: Hach Company Technical Information Series_-Booklet No. 11, 26 p., accessed January 4, 2018, at https://www.hach.com/asset-get.download. jsa?id=7639984474.

Smith, C.D., 2017a, Water surface images of Willow Creek Reservoir in Heppner, Oregon (2015 and 2016): U.S. Geological Survey data release, https://doi.org/10.5066/ F72B8WXK.

Smith, C.D., 2017b, Spatial water-quality measurements in Willow Creek Reservoir located in Heppner, Oregon, 2015-2016: U.S. Geological Survey data release, https://doi. org/10.5066/F7F18XM8.

Staehr, P.A., Bade, D., Van de Bogert, M.C., Koch, G.R., Williamson, C., Hanson, P., Cole, J.J., and Kratz, T., 2010, Lake metabolism and the diel oxygen technique: State of the science: Limnology and Oceanography: Methods, v. 8, p. 628-644.

Stone, M.L., Graham, J.L., and Gatotho, J.W., 2013, Model documentation for relations between continuous real-time and discrete water-quality constituents in Cheney Reservoir near Cheney, Kansas, 2001-2009: U.S. Geological Survey OpenFile Report 2013-1123, 114 p.

Stumpf, R.P., 2001, Applications of satellite ocean color sensors for monitoring and predicting harmful algal blooms: Human and Ecological Risk Assessment, v. 7, p. 1363-1368.
Urquhart, E.A., Schaeffer, B.A., Stumpf, R.P., Loftin, K.A., and Werdell, P.J., 2017, A method for examining temporal changes in cyanobacterial harmful algal bloom spatial extent using satellite remote sensing: Harmful Algae, v. 67, p. 144-152.

U.S. Environmental Protection Agency, 2013, Aquatic Life Ambient Water Quality Criteria for Ammonia - Freshwater 2013. EPA-822-R-13-001: U.S. Environmental Protection Agency Office of Water EPA 822-R-13-001, 255 p., accessed March 1, 2018, at https:/www.epa.gov/sites/production/ files/2015-08/documents/aquatic-life-ambient-water-qualitycriteria-for-ammonia-freshwater-2013.pdf.

U.S. Environmental Protection Agency, 2015, A Compilation of Cost Data Associated with the Impacts and Control of Nutrient Pollution. EPA 820-F-15-096: U.S. Environmental Protection Agency Office of Water EPA 820-F-15-096, 110 p., accessed December 5, 2017, at https://www.epa.gov/sites/ production/files/2015-04/documents/nutrient-economicsreport-2015.pdf.

U.S. Environmental Protection Agency, 2017, Recommendations for Cyanobacteria and Cyanotoxin Monitoring in Recreational Waters. EPA 820-R-17-001: U.S. Environmental Protection Agency Office of Water EPA 820-R-17-001, 15 p., accessed December 5, 2017, at https://www.epa.gov/sites/ production/files/2017-07/documents/08_july_3_monitoring _ document_508c_7.5.17.pdf.

U.S. Geological Survey, 2018a, USGS water data for Oregon: National Water Information System, Web Interface, accessed April 27, 2018, at https://waterdata.usgs.gov/or/nwis.

U.S. Geological Survey, 2018b, USGS data grapher and data tabler: U.S. Geological Survey Web site, accessed February 27, 2018, at http://or.water.usgs.gov/grapher/.

Van der Merwe, D., and Price, K.P., 2015, Harmful algal bloom characterization at ultra-high spatial and temporal resolution using small unmanned aircraft systems: Toxins, v. 7, p. 1065-1078.

Vézie, C., Brient, L., Sivonen, K., Bertru, G., Lefeuvre, J.C., and Salkinoja-Salonen, M., 1998, Variation of microcystin content of cyanobacterial blooms and isolated strains in Lake GrandLieu (France): Microbial Ecology, v. 35, p. 126-135.

Wagner, R.J., Boulger, R.W., Jr., Oblinger, C.J., and Smith, B.A., 2006, Guidelines and standard procedures for continuous water-quality monitors-Station operation, record computation, and data reporting: U.S. Geological Survey Techniques and Methods, book 1, chap. D3, accessed April 27, 2018, at http://pubs.water.usgs.gov/tm1d3.

Wilde, F.D., Radtke, D.B., Gibs, J., and Iwatsubo, R.T., eds., 2004 with updates through 2009, Processing of water samples (ver. 2.2): U.S. Geological Survey Techniques of WaterResources Investigations, book 9, chap. A5, April 2004, accessed November 22, 2017, at http://pubs.water.usgs.gov/ twri9A5/. 
Publishing support provided by the U.S. Geological Survey Science Publishing Network, Tacoma Publishing Service Center

For more information concerning the research in this report, contact the Director, Oregon Water Science Center

U.S. Geological Survey

2130 SW 5th Avenue

Portland, Oregon, 97201

https://www.usgs.gov/centers/or-water 
里

g)

옹

옹 